\title{
Modeling the physiology of the aquatic temnospondyl Archegosaurus decheni from the early Permian of Germany
}

\author{
Florian Witzmann $^{1}$ and Elizabeth Brainerd ${ }^{2}$ \\ ${ }^{1}$ Museum für Naturkunde, Leibniz-Institut für Evolutions- und Biodiversitätsforschung, Invalidenstraße 43, 10115 Berlin, \\ Germany \\ ${ }^{2}$ Department of Ecology and Evolutionary Biology, Brown University, Providence, RI 02912, USA
}

Correspondence to: Florian Witzmann (florian.witzmann@mfn-berlin.de)

Received: 21 December 2016 - Revised: 16 February 2017 - Accepted: 16 February 2017 - Published: 2 March 2017

\begin{abstract}
Physiological aspects like heat balance, gas exchange, osmoregulation, and digestion of the early Permian aquatic temnospondyl Archegosaurus decheni, which lived in a tropical freshwater lake, are assessed based on osteological correlates of physiologically relevant soft-tissue organs and by physiological estimations analogous to airbreathing fishes. Body mass (M) of an adult Archegosaurus with an overall body length of more than $1 \mathrm{~m}$ is estimated as $7 \mathrm{~kg}$ using graphic double integration. Standard metabolic rate (SMR) at $20^{\circ} \mathrm{C}\left(12 \mathrm{~kJ} \mathrm{~h}^{-1}\right)$ and active metabolic rate (AMR) at $25^{\circ} \mathrm{C}\left(47 \mathrm{~kJ} \mathrm{~h}^{-1}\right)$ were estimated according to the interspecific allometry of metabolic rate (measured as oxygen consumption) of all fish $\left(V_{\mathrm{O}_{2}}=\right.$ $4.8 \mathrm{M}^{0.88}$ ) and form the basis for most of the subsequent estimations. Archegosaurus is interpreted as a facultative air breather that got $\mathrm{O}_{2}$ from the internal gills at rest in wellaerated water but relied on its lungs for $\mathrm{O}_{2}$ uptake in times of activity and hypoxia. The bulk of $\mathrm{CO}_{2}$ was always eliminated via the gills. Our estimations suggest that if Archegosaurus did not have gills and released $100 \% \mathrm{CO}_{2}$ from its lungs, it would have to breathe much more frequently to release enough $\mathrm{CO}_{2}$ relative to the lung ventilation required for just $\mathrm{O}_{2}$ uptake. Estimations of absorption and assimilation in the digestive tract of Archegosaurus suggest that an adult had to eat about six middle-sized specimens of the acanthodian fish Acanthodes (ca. $8 \mathrm{~cm}$ body length) per day to meet its energy demands. Archegosaurus is regarded as an ammonotelic animal that excreted ammonia $\left(\mathrm{NH}_{3}\right)$ directly to the water through the gills and the skin, and these diffusional routes dominated nitrogen excretion by the kidneys as urine. Osmotic influx of water through the gills had to be compensated for by production of dilute, hypoosmotic urine by the
\end{abstract}

kidneys. Whereas Archegosaurus has long been regarded as a salamander-like animal, there is evidence that its physiology was more fish- than tetrapod-like in many respects.

\section{Introduction}

Quantitative modeling of an extinct animal's physiology may lead to a better understanding of its mode of life, including activity, breathing, feeding, or habitat preferences. However, this is not an easy task since crucial soft-tissue organs like gills, lungs, intestines, or other internal organs are usually not preserved in fossils. Therefore, studies on the paleophysiology of vertebrates have to rely on osteological correlates of the skeleton (e.g., Janis and Keller, 2001; Wedel, 2003; Schoch and Witzmann, 2011; Benson et al., 2012). Complementary to osteological correlates, the extant phylogenetic bracket can be applied and the fossil animal is compared with its closest living relatives (Bryant and Russell, 1992; Witmer, 1995, 1998). The present study deals with the physiology of the long-extinct tetrapod Archegosaurus decheni, a Paleozoic temnospondyl. Temnospondyls are basal tetrapods and range from the late early Carboniferous to the early Cretaceous (Schoch, 2014). Most researchers regard temnospondyls as stem amphibians, a group of which, the dissorophoids, gave rise to lissamphibians, i.e., frogs, salamanders, and caecilians (Ruta and Coates, 2007; Sigurdsen and Green, 2011; Schoch, 2014; but see Marjanović and Laurin, 2013, for an alternative view). Whereas dissorophoid temnospondyls usually resemble extant salamanders in body size and proportions, the majority of non-dissorophoid temnospondyls were much larger ( $1 \mathrm{~m}$ or more; some Mesozoic forms even grew up to $6 \mathrm{~m}$ in 
length) and often had a superficially crocodilian-like habitus. The physiology of such comparatively large temnospondyls is of interest because although they belong to the crowngroup Tetrapoda, they have neither closely related extant relatives nor an extant physiological analog: large, crocodilianlike non-amniotic tetrapods have been extinct since the early Cretaceous and were ecologically replaced by the superficially similar archosaurs, especially crocodilians. The skeletal morphology of non-dissorophoid temnospondyls differs from that of lissamphibians, not only in size and proportions but also in the much larger degree of ossification of the skeleton and the presence of an extensive cover of bony dermal scales. How can we imagine such animals breathing and feeding, and what was their metabolic rate? Were they merely "giant toads", as can sometimes be read in the popular literature?

This study is an attempt to assess certain aspects of the physiology of the large (more than $1 \mathrm{~m}$ adult size) Permian non-dissorophoid temnospondyl Archegosaurus decheni, including heat balance, gas exchange, osmoregulation, feeding, and digestion, based on a survey of osteological correlates in this temnospondyl and by virtue of theoretical calculations based on the physiology of extant vertebrates (Withers, 1992). In doing so, we are aware of the limitations of such an attempt: there are numerous sources of error, ranging from wrong prerequisites like inaccurate estimation of body mass to the choice of inappropriate extant animals for comparison. The older the geological age of the animal is, and the more distantly related it is to extant forms, the more difficult the evaluation of its physiology is. Therefore, we regard this study as an assessment of the physiology of Archegosaurus, rather than a reconstruction (which is not possible). Our aim is to show how its physiology could have been, not how it definitively was. Consequently, we replace the term "calculation" with "estimation" throughout this study. The term calculation would imply that the results were based on exact physiological measurements and represented the only true scenario, which is not possible for a fossilized animal. All estimations can be found in Appendix A.

Archegosaurus decheni was chosen for this study for the following reasons. First, it is one of the most intensively studied temnospondyls with numerous well-preserved specimens showing the cranial and postcranial skeleton and even some soft parts of the skin and the larval external gills, and its ontogeny from small larvae to large adults is also well documented (von Meyer, 1858; Hofker, 1926; Gubin, 1997; Witzmann, 2006a, b; Witzmann and Schoch, 2006). Second, some aspects of the skeleton, such as the morphology, the ribs, and the hyobranchial apparatus, are quite generalized in Archegosaurus (Witzmann and Schoch, 2006; Witzmann, 2013), and therefore the results of this study may also be valid for many other temnospondyls. Third, the paleoenvironment of Archegosaurus and its ecological role in the food web has been studied in detail based on sedimentological data, the accompanying fauna, and intestine fillings (Boy,
1993, 1994; Witzmann, 2004a; Kriwet et al., 2008). Fourth, Archegosaurus is a phylogenetically highly relevant taxon that is an early-diverging member of the Stereospondylomorpha (Fig. 1), a diverse clade of large-growing, crocodilianlike temnospondyls of the late Permian and the Triassic (Schoch, 2013; Eltink and Langer, 2014). Better knowledge of the paleophysiology of Archegosaurus may shed light on the ancestral lifestyle of stereospondylomorphs as well as the evolution of this large extinct clade that dominated the Triassic fluvio-lacustrine ecosystems (Schoch and Milner, 2000; Fortuny et al., 2011, 2016).

Archegosaurus decheni is an early Permian temnospondyl that superficially resembled a long-snouted crocodilian or gharial. Its occurrence is restricted to the large Lake Humberg in the Permo-Carboniferous Saar-Nahe Basin in southwestern Germany (see Sect. 2) (Boy, 1994; Witzmann, 2006a). Archegosaurus is known from hundreds of specimens, some of which are almost complete articulated skeletons. Specimen size ranges from about $15 \mathrm{~cm}$ long larvae with external gills to adults that measure more than $1.5 \mathrm{~m}$ in length. The long, deep-swimming tail, the presence of lateral line sulci on the skull, the poorly ossified and comparatively weak fore- and hind limbs, and the retention of branchial teeth on the gill arches indicate that the large adults were also primarily aquatic animals and were capable of only short sojourns on land (Witzmann, 2006a; Witzmann and Schoch, 2006). Adults breathed via their lungs, whose presence is indicated by the extant phylogenetic bracket (Schoch and Witzmann, 2011). However, although neither ossified gill arches nor a postbranchial lamina of the shoulder girdle are preserved, adult Archegosaurus probably also breathed via fishlike internal gills and therefore was a bimodal breather. This assumption is based on the presence of the aforementioned branchial teeth that also indicate open gill clefts in large specimens (Witzmann, 2013) and on the fact that more derived stereospondylomorphs, the stereospondyls, possessed internal gills (e.g., trematosauroids, plagiosaurids, brachyopoids; Schoch and Witzmann, 2011; Witzmann, 2013). Furthermore, it is highly improbable that internal gills reappeared after they had been lost in the ancestral group. Thus, its mainly aquatic mode of life and the fact that both more basal (e.g., Trimerorhachis, Sclerocephalus) and more derived temnospondyls than Archegosaurus possessed internal gills strongly suggest that it possessed internal gills as an adult. Otherwise, if adult Archegosaurus had lost its gills completely, it should be secondarily aquatic and derived from a terrestrial ancestor (see discussion of the loss of gills in aquatic and terrestrial tetrapods in Janis and Farmer, 1999), but there is no existing evidence for this. Therefore, Archegosaurus is regarded here as a primarily aquatic tetrapod that breathed via internal gills and lungs as an adult and possessed external gills as a larva, analogous to extant lepidosirenid lungfishes and polypterid actinopterygians (Graham, 1997). 


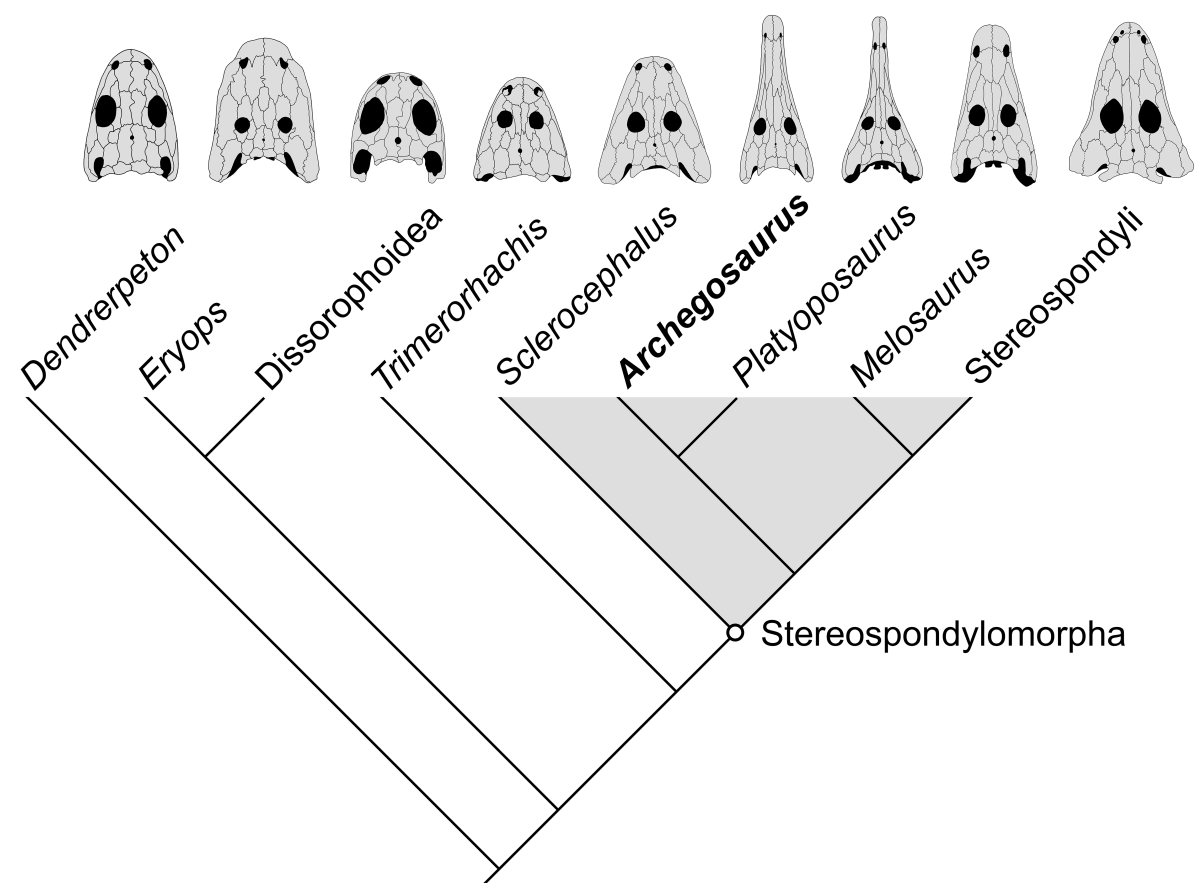

Figure 1. Cladogram of temnospondyls (simplified after Eltink and Langer, 2014) showing the phylogenetic relationships of Archegosaurus decheni. The Dissorophoidea are the putative stem group of lissamphibians (Schoch, 2014, and references therein). The skulls are redrawn after Schoch and Milner $(2000,2014)$ with the exception of Archegosaurus, which is redrawn after Witzmann (2006a).

\section{Paleoenvironment and habitat of Archegosaurus}

The Saar-Nahe Basin in southwestern Germany contains a series of late Carboniferous to early Permian sediments of successive, usually short-lived (10-1000 years), intermontane lakes within the Variscan mountain belt and yielded a large number of fossil vertebrates like bony and cartilaginous fishes and aquatic tetrapods (Boy, 1994; Schoch, 2014). Whereas Schultze and Soler-Gijón (2004) proposed that the lakes of the Saar-Nahe Basin were subject to marine influences, recent geochemical analyses indicate that these lakes were nonmarine in origin (Fischer et al., 2013). Archegosaurus decheni has only been described so far from sediments of the final stage of the deep, $80 \mathrm{~km}$ long Lake Humberg, which was one of the largest and longest-lasting lakes of the Saar-Nahe Basin. Its sediments are Sakmarian, lowermost Permian, in age (Meisenheim Formation, uppermost Odernheim Subformation; Schindler, 2007; Boy and Schindler, 2012). By far the most specimens of Archegosaurus have been found in layers and siderite concretions (or geodes) of the clay ironstone facies (tonsteinlager) of the Humberg black shale layers of Lebach near Saarbrücken. The fish fauna of the clay ironstone facies encompasses the plankton-feeding acanthodian Acanthodes and, among paleoniscoids, the plankton-feeding Paramblypterus and the piscivorous or benthivorous Rhabdolepis and Elonichthys (Boy, 1994; Boy and Schindler, 2012). Xenacanthid sharks are represented by Triodus, Xenacanthus, and Lebachacanthus (Boy, 1994), whereas the lungfish Conchopoma is the only known sarcopterygian fish in Lake Humberg (Schultze, 1975). A second temnospondyl that is contemporary with Archegosaurus but much less frequent in number, Glanochthon latirostris, occurred in Lake Humberg (Boy, 1993; Schoch and Witzmann, 2009). Intestine fillings show that Glanochthon also fed mainly on Acanthodes, similar to Archegosaurus (Boy, 1994; Witzmann, 2004a). In turn, at least the larvae of both temnospondyls were fed by the xenacanthid sharks in Lake Humberg, as shown by intestine fillings (Boy, 1993, 1994; Kriwet et al., 2008).

During the Permo-Carboniferous, the Saar-Nahe Basin was located in the tropical region, about $10^{\circ}$ north of the Equator (Boy and Sues, 2000; Schindler, 2007), with a monsoonal climate (Patzowsky et al., 1991). The lakes were probably situated about $2000 \mathrm{~m}$ above sea level (Becq-Giraudon et al., 1996). The water temperature of a lake is critical for the metabolism of its inhabitants (especially fishes and amphibians as ectothermic vertebrates). Unfortunately, no reliable data concerning water temperature in Lake Humberg and the other known lakes of the Saar-Nahe Basin exist. Therefore, the water temperature is estimated based on extant large tropical lakes with a similar high altitude. Baxter et al. (1965) reported the water temperature of different African tropical lakes. One of them, Lake Bunyonyi, is comparable to the presumed altitude of Lake Humberg: it is located $1973 \mathrm{~m}$ above sea level and the temperature to a depth of $10 \mathrm{~m}$ is about 

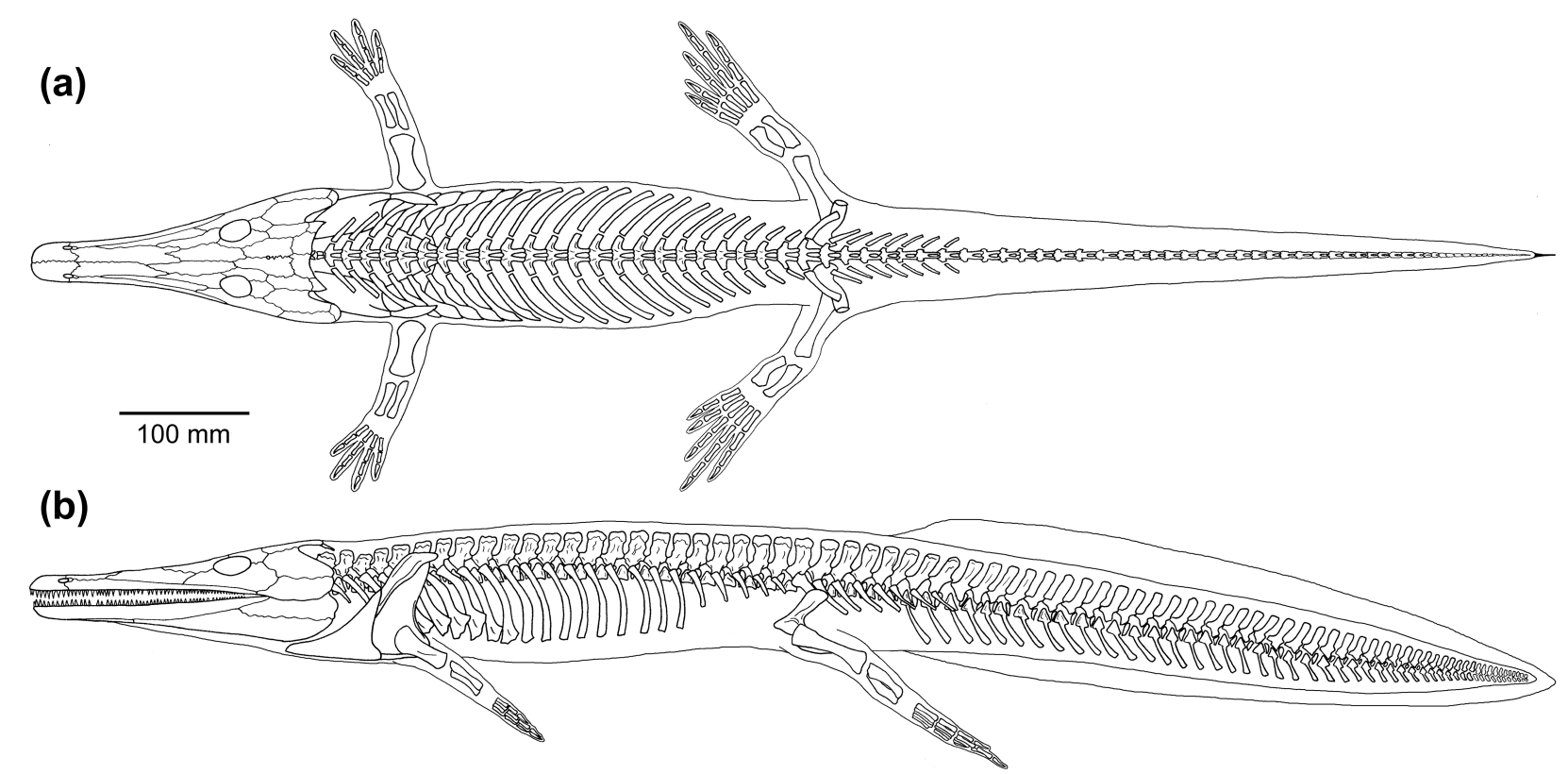

Figure 2. Skeletal reconstruction with body outline of an adult specimen of Archegosaurus decheni from the early Permian of the Saar-Nahe Basin, Germany. (a) Dorsal view; (b) lateral view. Redrawn and modified after Witzmann (2004a) and Witzmann and Schoch (2006).

$20^{\circ} \mathrm{C}$ in June. Analogously, the temperature of Lake Humberg close to the water surface is set here at $20^{\circ} \mathrm{C}$.

The early Permian atmosphere differed from today's atmosphere especially by its significantly higher $\mathrm{O}_{2}$ level, which probably accounted for about $29 \%$ by volume according to recent models (Berner, 2006; Glasspool and Scott, 2010), in contrast to today's $20.95 \%$ (Heldmaier and Neuweiler, 2004). Today's $\mathrm{CO}_{2}$ level in the atmosphere is $0.043 \%$ (Earth System Research Laboratory, Global Monitoring Division, June 2015, http://www.esrl.noaa.gov/gmd/ccgg/trends/). According to Berner and Kothavala (2001) the $\mathrm{CO}_{2}$ content in the early Permian was probably only slightly higher than today and is set here as $0.047 \%$.

\section{Body mass and body surface area of the Archegosaurus model}

To make an estimate of the metabolism of an animal, it is indispensable to know its body mass. The relationship between body mass and metabolic rate is described by the power curve (Withers, 1992; Heldmaier and Neuweiler, 2004):

$E_{\text {metab }}=a \mathrm{M}^{b}$

in which $E_{\text {metab }}$ is the rate of metabolic energy use $\left(\mathrm{kJ} \mathrm{h}^{-1}\right)$, $\mathrm{M}$ is body mass in grams, $b$ is the mass exponent, and $a$ is the intercept of the $y$ axis, i.e., metabolic rate of mass $=1 \mathrm{~g}$ (Withers, 1992; Heldmaier and Neuweiler, 2004).

In this study, we use a volumetric model called graphic double integration (GDI) to estimate the body mass of an adult Archegosaurus specimen. This method was developed by Jerison (1973), who estimated endocast volumes of the brain of fossil vertebrates. Hurlburt (1999) was the first to apply GDI to estimate the body mass of complete specimens, including the synapsid Edaphosaurus as well as extant squamates and crocodilians. In GDI, the body (or a part of it) is described as an elliptical cylinder to calculate its volume (Jerison, 1973; Hurlburt, 1999). Multiplication of the calculated volume by the (assumed) specific gravity (SG) of the animal yields the estimated body mass.

Since no mounted skeleton of Archegosaurus is available, we used the graphic skeletal reconstruction of an adult specimen of Archegosaurus with a total length of the skeleton (from the anterior end of the premaxillae to the tip of the tail) of $125 \mathrm{~cm}$ (Fig. 2). The drawings show the skeleton in left lateral and dorsal view and are based on the skeletal descriptions and drawings of Archegosaurus by Witzmann (2004a) and Witzmann and Schoch (2006). The presumed body outline was drawn around the skeleton in both views, based on comparison with extant salamanders (like the giant salamanders Andrias and Cryptobranchus) and crocodilians (like the false gharial Tomistoma). The reconstruction with body outline is $126 \mathrm{~cm}$ long, i.e., adding $1 \mathrm{~cm}$ to the length of the reconstructed skeleton. Archegosaurus is reconstructed here with a deep fin, similar to aquatic salamanders and salamander larvae. The outline of the axial body (consisting of skull, trunk, and the muscular part of the tail, but not the fin, which is too thin and can therefore be neglected) and the fore- and hind limbs were treated separately in GDI.

The estimation of body mass for the Archegosaurus model based on GDI (see estimation in Appendix A1 and Fig. 3) 

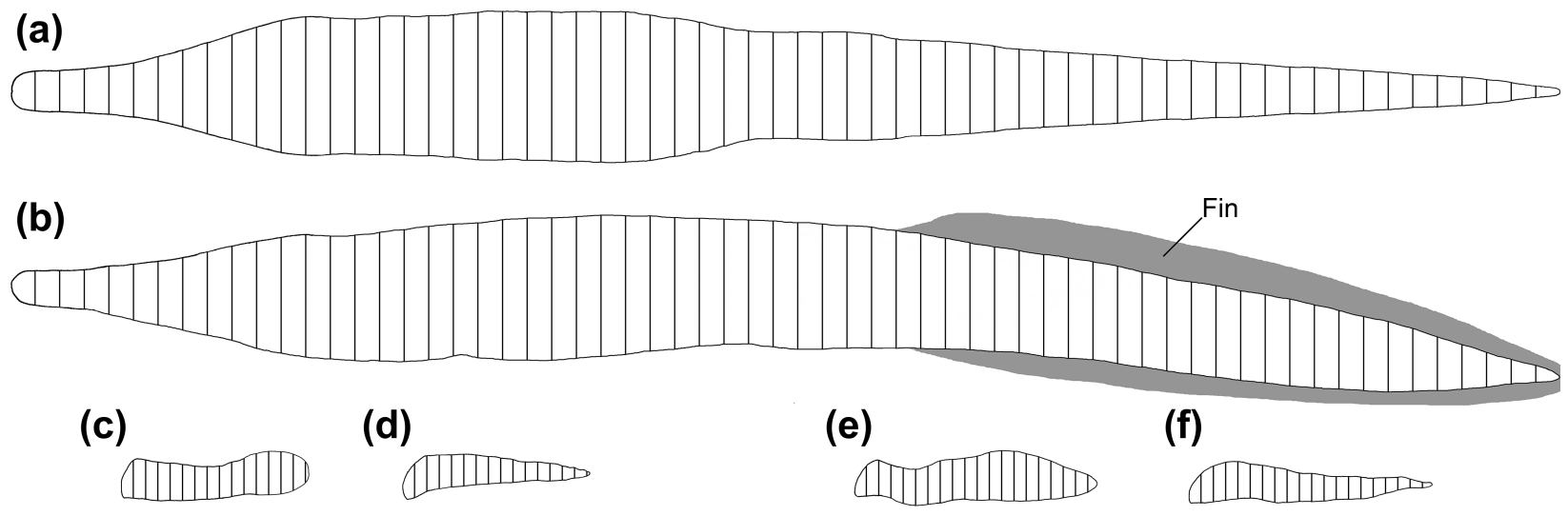

Figure 3. Graphic double integration (GDI) of Archegosaurus decheni to estimate body mass and body surface area. (a, b) Outline of the axial body (i.e., head, trunk, and tail) in (a) dorsoventral and (b) lateral view with 62 slices through the body, each separated by a distance of $2 \mathrm{~cm}$; the fin of the tail is shown in grey; (c, d) outline of a forelimb in dorsoventral (c) and lateral view (d) with 15 slices, each separated by a distance of $1 \mathrm{~cm}$; (e, f) outline of a hind limb in dorsoventral (e) and lateral view (f) with 19 slices, each separated by a distance of $1 \mathrm{~cm}$.

yielded a body mass of $7 \mathrm{~kg}$, with an uncertainty of about $\pm 1 \mathrm{~kg}$. Estimation of body surface area of the Archegosaurus model yielded a total body surface area of $4000 \mathrm{~cm}^{2}$ (see estimation in Appendix A2).

\section{Metabolic rate and body temperature of the Archegosaurus model}

A recent analog for Archegosaurus decheni among extant ectothermic vertebrates could be selected from among extant fishes or lissamphibians. Frogs and caecilians are not appropriate analogs since they are too small and the body mass of even their largest representatives is far below the estimated body mass of Archegosaurus. Although giant salamanders of the genus Andrias may reach body sizes similar to adult Archegosaurus (Ultsch, 2012), salamanders are derived as having a very low metabolic rate (Licht and Lowcock, 1991) and are therefore problematic as extant analogs. For these reasons, and because most non-dissorophoid temnospondyls differ conspicuously from lissamphibians in many respects and are more similar to fishes in the possession of fish-like internal gills, we have chosen the interspecific allometry of metabolic rate of all fish provided by Withers (1992, tables 4-5):

$E_{\text {metab }}=4.8 \mathrm{M}^{0.88}\left[20^{\circ} \mathrm{C}\right]$.

Measured scaling exponents for fishes vary widely, with differences due both to methodology and true variation among species, lifestyles, and habitats (Killen et al., 2010). The scaling relationship we have chosen here produces metabolic rates that are on the high end for fishes, which may be justified by the finding that benthic fishes tend to show higher scaling exponents (Killen et al., 2010), and we presume that Archegosaurus lived a primarily benthic existence. However, an alternative interspecific scaling relationship for all fishes, $E_{\text {metab }}=2.5 \mathrm{M}^{0.70}$ (Withers, 1992), yields metabolic rates that are nearly 10 times lower. The uncertainty produced by the variation in scaling relationships is much greater than that from uncertainty in body mass. Variation from the two allometric equations above produces resting metabolic rates in the range of $1.2-12 \mathrm{~kJ} \mathrm{~h}^{-1}$ for a $7 \mathrm{~kg}$ specimen, and variation in mass from 6 to $8 \mathrm{~kg}$ yields a range of just $10-13 \mathrm{~kJ} \mathrm{~h}^{-1}$ for the higher scaling relationship and 1.1-1.3 for the lower one (Appendix A1). Hence, precise estimates of body mass are valuable for reconstructing many aspects of extinct physiology but do not matter as much as the scaling relationship selected for estimates of metabolic rate.

\subsection{Standard and active metabolic rate at $20^{\circ} \mathrm{C}$}

As a stem group amphibian, Archegosaurus decheni was undoubtedly ectothermic. Because of the high thermal conductivity of water and the presence of gills that bring blood in close contact with the ambient water, Archegosaurus probably possessed a body temperature that coincided closely with the ambient temperature of the surrounding water (estimated here as mean $20^{\circ} \mathrm{C}$ in Lake Humberg), as in most extant fishes (Heldmaier and Neuweiler, 2004). Thus, the standard metabolic rate at $20^{\circ} \mathrm{C}$ (SMR $20^{\circ} \mathrm{C}$ ) can be estimated as $12 \mathrm{~kJ} \mathrm{~h}^{-1}$ and the active metabolic rate at $20^{\circ} \mathrm{C}\left(\mathrm{AMR} 20^{\circ} \mathrm{C}\right)$ as $30 \mathrm{~kJ} \mathrm{~h}^{-1}$ (see estimation in Appendix A3).

\subsection{Increasing active metabolic rate at higher temperature}

All physiological functions in an animal are temperature dependent, and each organism has its species-specific thermal optimum at which it attains its maximum efficiency (Heldmaier and Neuweiler, 2004). In analogy with aquatic amphibians, Archegosaurus was certainly capable of behavioral 
thermoregulation, i.e., by changing locations in the water according to the available water temperature in the environment (Hillman et al., 2009). Archegosaurus could have raised its body temperature by staying in extremely shallow inshore water that was warmed up by the radiant heat of the sun. In turn, body temperature could be lowered by visiting deeper water layers or those parts of the shore that were covered by dense vegetation. Basking on land similar to squamates (Drane and Webb, 1980), crocodilians (Grigg and Seebacher, 2001), or specialized anurans (Hillman et al., 2009), and as assumed by Carroll et al. (2005) for Devonian tetrapods, was performed for a rather short time, if at all, by Archegosaurus because of the danger of desiccation via the gills and the skin that was probably similar to that of bony fishes (Witzmann, 2011). Resting in warm inshore water enabled Archegosaurus to raise its metabolic rate and to search more actively for fishes in the open water. For example, $25^{\circ} \mathrm{C}$ is the preferred body temperature for salamander larvae (Withers, 1992, p. 134), and a water temperature $T_{\mathrm{a}}$ of $25^{\circ} \mathrm{C}$ can certainly be expected in shallow water at the shore of Lake Humberg. Furthermore, it can be assumed that $T_{\mathrm{a}}$ was subject to seasonal fluctuations in the monsoonal tropical climate. Therefore, AMR at $25^{\circ} \mathrm{C}$ is estimated as $47 \mathrm{~kJ} \mathrm{~h}^{-1}$ (see estimation in Appendix A4). Consequently, in the model, Archegosaurus was able to raise its metabolic rate by a factor of more than 1.5 in water with $T_{\mathrm{a}}=25^{\circ} \mathrm{C}$ as compared to $T_{\mathrm{a}}=20^{\circ} \mathrm{C}$.

\subsection{Average daily metabolic rate (ADMR)}

For estimation of the average daily metabolic rate (ADMR), the diel activity of the Archegosaurus model has to be estimated; i.e., how many hours was the animal active per day? The northern pike (Esox lucius) is active for $4.8 \mathrm{~h}$ per day (Diana, 1980), and a similar value of $3.9 \mathrm{~h}$ per day was reported by Nifong et al. (2014) for the American alligator (Alligator mississippiensis). Bracketed by these data of a bony fish and an alligator, we guess that Archegosaurus may have been active for $4.5 \mathrm{~h}$ per day when it was swimming and foraging in the open water of the lake. With this assumption, and assuming an active body temperature of $25^{\circ} \mathrm{C}$, the average daily metabolic rate can be estimated for the Archegosaurus model as $19 \mathrm{~kJ} \mathrm{~h}^{-1}$ (see estimation in Appendix A5).

\section{How did Archegosaurus breathe?}

As outlined above, the extant phylogenetic bracket indicates that Archegosaurus decheni possessed lungs for air breathing, and apart from larval external gills (Fig. 4), there is direct and indirect evidence that adults possessed fish-like internal gills (Fig. 5). Unlike in lissamphibians, the skin of Archegosaurus can be ruled out as a major site of gas exchange for the following reasons: (1) the soft-tissue skin of temnospondyls has been shown to have been thicker, denser,

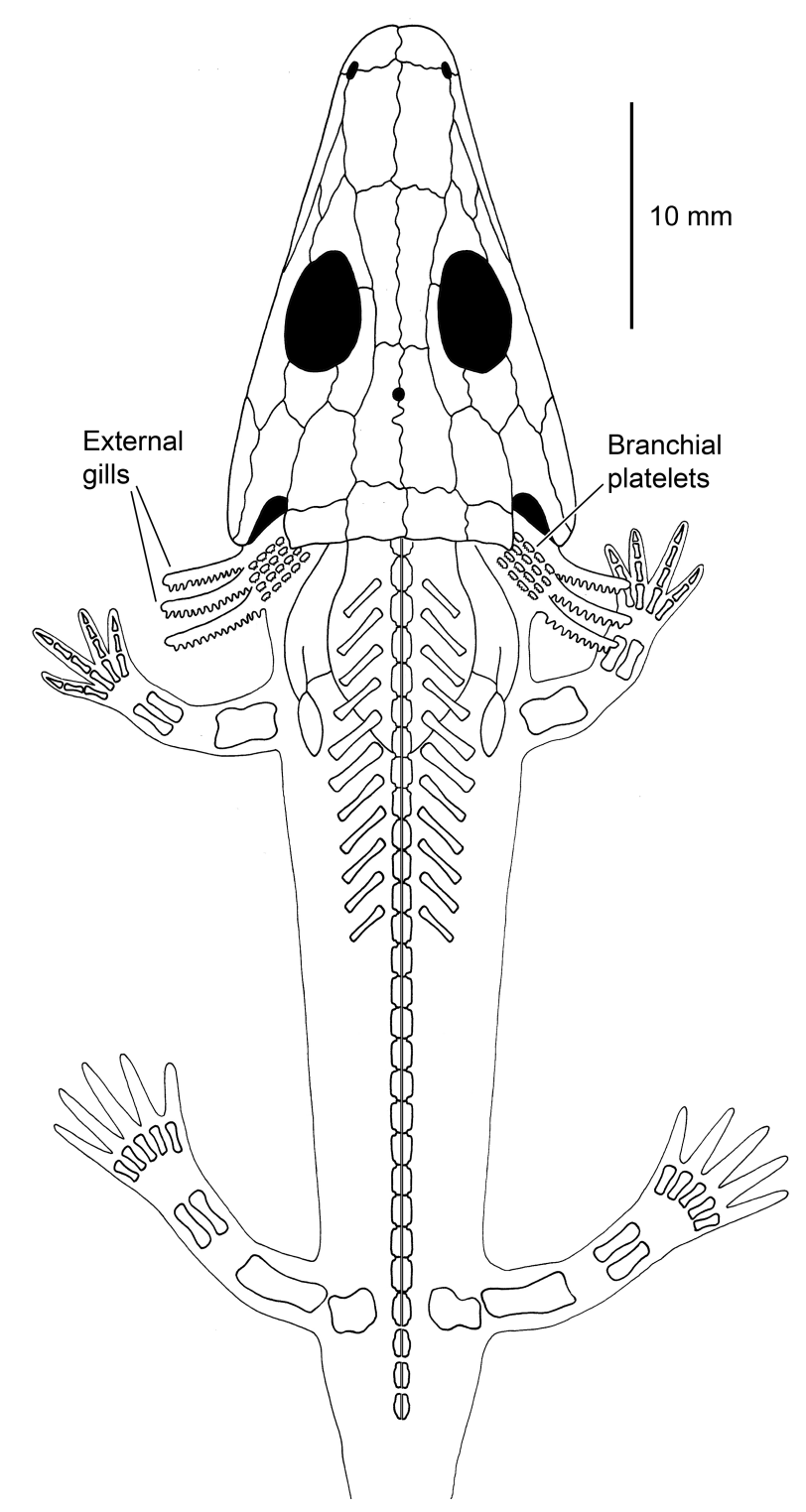

Figure 4. Reconstruction of a small larva of Archegosaurus decheni showing three pairs of external gills and branchial platelets. Redrawn and modified after Witzmann (2004a).

and more keratinized than in lissamphibians, whose permeable skin appears to be derived (Maddin et al., 2007; Witzmann et al., 2010); (2) the complete postcranial body of Archegosaurus was covered by bony dermal scales (Witzmann, 2007); and (3) Archegosaurus was distinctly larger than lissamphibians (with the exception of the highly derived giant salamander Andrias) and thus had an unfavorable ratio of surface area to volume. This indicates that the skin of Archegosaurus was probably at best an accessory breathing organ as in certain fishes that supplied the skin (but not other organs) with oxygen (Graham, 1997). Therefore, the skin will not be considered as a breathing organ in the following, and we will concentrate on lung and gill breathing. 


\subsection{Evidence of the mode of lung ventilation in Archegosaurus}

Extant amphibians and lung-breathing fishes fill their lungs by vertical movements of the buccal floor that press air from the buccal cavity into the lungs without involvement of trunk musculature (buccal pump mechanism; Brainerd, 1999). In contrast, extant amphibians (but not fishes) use contraction of the transverse abdominal musculature for exhalation (Brainerd et al., 1993; Brainerd, 1998; Brainerd and Monroy, 1998; Brainerd and Simons, 2000; Simons et al., 2000; Brainerd and Owerkowicz, 2006). The straight, short ribs of extant amphibians play no functional role in lung breathing. In contrast, the lungs of amniotes are ventilated by movements of the rib cage (aspiration pump): action of the trunk muscles expands the thorax, generates negative pressure in the lungs, and air is drawn in (Brainerd, 1999; Brainerd and Owerkowicz, 2006; Brainerd et al., 2016).

The ribs of small and middle-sized Archegosaurus are flattened, short, and straight and resemble those of extant salamanders (Fig. 4). In large specimens, the rib shafts are still flattened, but most presacral ribs (with the exception of cervical and lumbar ribs) are proportionally longer and slightly curved. The ribs of the thoracic region bear hook- or blade-like, posterodistal expansions (Fig. 2) (Witzmann and Schoch, 2006). The distal ends of the ribs are covered by periosteal bone, suggesting that no cartilaginous extensions connected the ribs to a ventral sternum. These morphological observations match the criteria of Janis and Keller (2001) for a rather rigid rib cage in basal tetrapods that could not be employed in costal aspiration. Therefore, it is assumed here that Archegosaurus drew air into its lungs by buccal pumping like extant amphibians or lungfishes. The extant phylogenetic bracket suggests that Archegosaurus used its ventral trunk musculature, the $\mathrm{m}$. transversus abdominis, for forcing air out of the lungs because this muscle is employed in exhalation in both amniotes and extant amphibians (Brainerd et al., 1993; Brainerd and Owerkowicz, 2006).

\subsection{Gill breathing in Archegosaurus}

\subsubsection{Evidence of gill types in Archegosaurus}

As outlined above, it can be assumed that fish-like internal gills were present in adult Archegosaurus because of phylogenetic reasoning and the presence of open gill clefts in adults, although the cartilaginous gill arches proper are not preserved. Internal gills do not occur in any living tetrapod and are restricted among extant vertebrates to fish-like vertebrates (Coates and Clack, 1991; Schoch and Witzmann, 2011). How can we assess whether the internal gills of Archegosaurus were used for uptake of most of the necessary $\mathrm{O}_{2}$ and for $\mathrm{CO}_{2}$ elimination, as in most extant fishes, or if they mainly had the function of eliminating $\mathrm{CO}_{2}$, as in most air-breathing fishes (Graham, 1997)? Cru- cial in this point might be the fact that small and middlesized growth stages of Archegosaurus possessed three pairs of external gills (Fig. 4), which were completely lost in large specimens. The morphology of their gill rami and filaments is well preserved as carbonaceous imprints (Witzmann, 2004b). Similarly, larvae of lepidosirenid lungfishes (i.e., the African lungfish Protopterus and the South American lungfish Lepidosiren) possess four pairs of external gills, which can also be retained in large specimens of Protopterus annectens (Graham, 1997) and whose morphology is very similar to those of Archegosaurus. The internal gills of lepidosirenids are reduced to two holobranchs and one hemibranch (Burggren and Johansen, 1986). In lepidosirenids, external gills are accessory organs for the aquatic uptake of $\mathrm{O}_{2}$ in larvae and juveniles, which, in contrast to adults, are not obligate air breathers and get most of their $\mathrm{O}_{2}$ aquatically (Graham, 1997). This recalls the situation of polypterid actinopterygians (Polypterus and Erpetoichthys), which have paired lungs and breathe air as adults in $\mathrm{O}_{2}$-poor water and in phases of increased activity (Magid et al., 1970; Babiker, 1984; Pettit and Beitinger, 1985; Graham, 1997). In turn, polypterids possess only four gill arches (instead of five), and the internal gills are reduced to three holobranchs and one hemibranch (Britz and Johnson, 2003; Bartsch, 2004). However, air breathing starts quite late in ontogeny (Babiker, 1984); larvae and juveniles have one pair of external gills whose pinnate morphology is similar to that of the external gills of lepidosirenids and Archegosaurus but are attached to the hyoid arch rather than to the gill arches (Bartsch, 2004). Polypterids are capable of excursions on land and can be exposed to air for up to 6-8 h (Sacca and Burggren, 1982; Pettit and Beitinger, 1985; Pace and Gibb, 2011; Standen et al., 2014; Du et al., 2016). External gills also occur in larvae of lissamphibians (Duellman and Trueb, 1994), and especially the morphology of the three pairs of external gills in salamanders corresponds to that of lepidosirenids and Archegosaurus. However, whereas the external gills of temnospondyls and salamanders can be regarded as homologous structures, the external gills of larval lepidosirenids evolved convergently, and the external gills of polypterids also developed independently (Witzmann, 2004b). These extant examples show that external gills occur in larvae of bimodalbreathing vertebrates that have reduced their internal gills to a certain degree (lepidosirenids, polypterids) or have completely reduced them (lissamphibians) and use external gills for aquatic breathing until the lungs are fully functional.

Considering these facts, the presence of larval external gills in Archegosaurus may suggest that the internal gills were not completely developed and that the lungs may have played an important role in $\mathrm{O}_{2}$ intake in phases of hypoxia and during increased activity. However, the question is whether Archegosaurus had reduced its internal gills to such a large degree that it was an obligate air breather like adult lepidosirenid lungfishes or whether it was a facultative air breather like Polypterus and Erpetoichthys. In spite of 


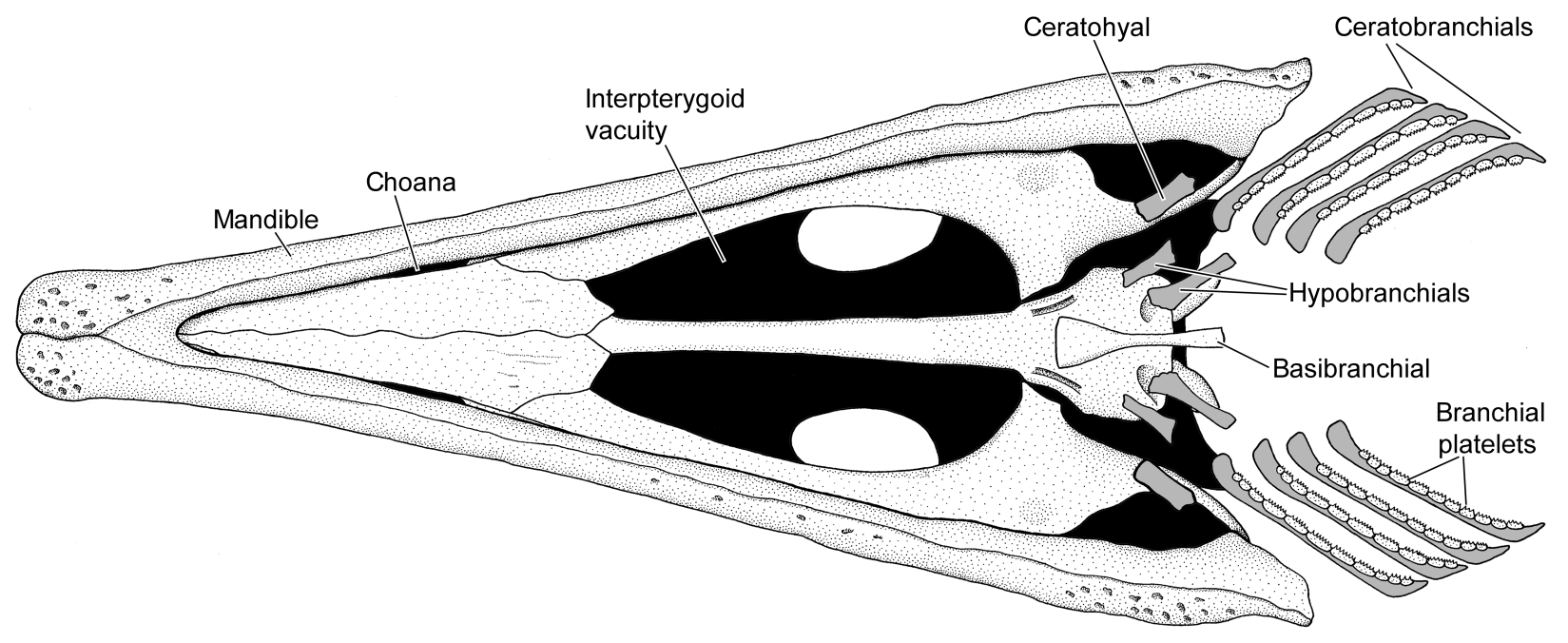

Figure 5. Skull, mandible and hyobranchial apparatus of an adult Archegosaurus decheni in ventral view. Cartilaginous elements are shown in grey. The denticulate bony platelets that covered the interpterygoid vacuities in life are not shown. Redrawn and modified after Witzmann (2006a, 2013).

the outer morphological similarities between Archegosaurus and lepidosirenids, like larval external gills on the branchial arches, we did not choose lepidosirenids as an extant ana$\log$ of Archegosaurus for breathing. This is because lepidosirenids - analogous to amniotes - are highly derived in possessing a high buffering capacity and low $\mathrm{pH}$ of the blood, and they therefore have the ability to release substantial amounts of $\mathrm{CO}_{2}$ via the lungs (Bassi et al., 2005). Lepidosirenids experience limited water availability or spend time estivating in dry burrows; thus, they have reduced gills to a large degree, to the point of not being able to use them sufficiently for $\mathrm{O}_{2}$ or $\mathrm{CO}_{2}$ exchange (de Moraes et al., 2005). Furthermore, lepidosirenids have reduced their internal gills to such a degree that they are obligate air breathers even in well-aerated water. The only reason to substantially reduce or eliminate gills is if a large amount of time is spent on land since gills would soon dry out. If a vertebrate is aquatic, there is no selective pressure to reduce the gills substantially, and it makes sense to always release $\mathrm{CO}_{2}$ and usually get $\mathrm{O}_{2}$ from the gills, except during aquatic hypoxia and times of activity (Brainerd, 2015). No estivation burrows of Archegosaurus are known, and it was probably less terrestrial than lepidosirenids. Therefore, and because its breathing physiology has been intensively studied (e.g., Magid et al., 1970; Babiker, 1984), we took Polypterus as an extant analog of Archegosaurus for estimation of the breathing rates.

Polypterids (or Cladistia) attain a maximum body length of 40-90 cm and are regarded as the sister group of all other extant actinopterygians (Graham, 1997; Bartsch, 2004). Similar to lepidosirenid lungfishes and tetrapods, polypterids possess paired lungs that originate ventrally from the pharynx (Lechleuthner et al., 1989; Graham, 1997; Brainerd, 2015). Dependency on air breathing increases with on- togenetic size in polypterids but never becomes obligatory in well-aerated water (Babiker, 1984; Graham, 1997). Polypterid lungs are very efficient and enable these fishes to rely completely on air breathing for $\mathrm{O}_{2}$ uptake when water is virtually devoid of oxygen (Babiker, 1984). However, the gills are always the principal site for $\mathrm{CO}_{2}$ release (Graham, 1997).

In summation, Archegosaurus is regarded here as a facultative air breather similar to polypterid fishes, meaning it got $\mathrm{O}_{2}$ from the gills when it was in well-aerated water but relied on its lungs for $\mathrm{O}_{2}$ uptake in times of activity and in oxygendepleted water. The bulk of $\mathrm{CO}_{2}$ was always eliminated via the gills.

\subsubsection{Ventilation of gills}

Oxygen is about 30 times less soluble in water than in air, and thus its availability for respiration is limited for animals that breathe water (Heldmaier and Neuweiler, 2004). To extract a sufficient quantity of $\mathrm{O}_{2}$, water-breathing animals have to pump a large amount of water continuously through their gills. In the majority of bony fishes, ventilation of the gills occurs through the action of two pumps, the relative size of which may vary between taxa (Hughes, 1960): (1) a positive pressure buccal force pump anterior to the gills, which is generated by movements of the lower jaw and buccal floor, and (2) an opercular suction pump that is generated by mediolateral movements of the opercular and branchiostegal apparatus posterolateral to the gills. Both pumps are usually also present in air-breathing fishes like extant lungfishes (Burggren and Johansen, 1986) and actinopterygians (Brainerd and Ferry-Graham, 2006). How did Archegosaurus ventilate its gills? Its larval external gills were probably periodi- 
cally moved back and forth to generate convective movement of water across the gill filaments so that $\mathrm{CO}_{2}$-rich water was dispersed and replaced by fresh, oxygenated water, similar to extant salamander larvae (Hillman et al., 2009). It is more difficult to imagine how Archegosaurus ventilated its internal gills because no tetrapod possesses an opercular apparatus, which was already reduced in tetrapodomorph fishes from Tiktaalik onwards (Daeschler et al., 2006). This means that Archegosaurus was not able to use an opercular pump, and therefore the buccal pump must have increased its importance for gill ventilation: vertical movements of the buccal floor pumped water in a posterior direction towards the gills, and this might have been associated with regular opening and closure of the mouth. This view is supported by the fact that the only ossified element of the hyobranchium in Archegosaurus (and many other aquatic temnospondyls) is the robust basibranchial (Witzmann, 2013) that was located on the buccal floor (Fig. 5). The basibranchial, especially its broadened, downturned anterior portion, was the insertion site of the rectus cervicis muscle, which aids in lowering the mandible when it is pulled posteroventrally, a mechanism that is probably plesiomorphic for gnathostomes (Lauder and Reilly, 1994). Among extant bony fishes, moray eels have lost the opercular apparatus and ventilate their gills solely by action of the buccal pump (Hughes, 1960; Farina et al., 2015); therefore, they have to move the lower jaw continuously (observations of moray eels ventilating their gills at rest in a public aquarium by $\mathrm{F}$. Witzmann suggest 30 depressions of the mandible per minute). In Archegosaurus, the opercular pump might have been functionally replaced to a certain degree by the flexibility of the cartilaginous gill arches. Similar to sharks (Hildebrand and Goslow, 1998) and larvae of lampreys (ammocoetes) (Brainerd and Ferry-Graham, 2006), contraction of the cartilaginous gill arches may have pressed water out of the pharynx and over the gills during exhalation, and their elastic recoil during inhalation might have served as a suction pump and have drawn water from the mouth cavity towards the gills. In spite of this, the ventilation of internal gills in Archegosaurus and other basal tetrapods was certainly less effective than in bony fishes with a functional opercular and branchiostegal apparatus.

\subsection{Breathing rate in the Archegosaurus model}

The assumption of the following estimations of $\mathrm{O}_{2}$ uptake is that Archegosaurus was required to meet $100 \%$ of its oxygen needs from gas exchange in the lungs in times of hypoxia in water or during increased activity. The assumption of the following estimations for $\mathrm{CO}_{2}$ release is that the internal gills of Archegosaurus were the primary site of $\mathrm{CO}_{2}$-gas exchange and Archegosaurus maintained low bicarbonate buffer activity in the blood and high blood pH (Witzmann, 2016). If Archegosaurus did not have gills and released $100 \%$ of the $\mathrm{CO}_{2}$ from its lungs, and maintained a low $\mathrm{CO}_{2}$ buffering capacity, it would have to breathe much more frequently to re- lease enough $\mathrm{CO}_{2}$, relative to the lung ventilation required for just $\mathrm{O}_{2}$ uptake. That scenario is also modeled below. Assumptions in the following estimations are based on the gas exchange strategy of Polypterus senegalus, which is taken as the extant analog of the Archegosaurus model, which involves $\mathrm{O}_{2}$ uptake in the lungs and $\mathrm{CO}_{2}$ release from the gills as assumed for Archegosaurus.

\subsubsection{Lung morphometric data of the Archegosaurus model based on Polypterus senegalus}

Lung morphometric data (lung volume, tidal volume, etc.) are available for Polypterus senegalus (Magid et al., 1970; Babiker, 1984; Brainerd, 1994). Consequently, the lung volume $V_{\mathrm{L}}$ in the Archegosaurus model can be estimated as $1400 \mathrm{~mL}$ and the tidal volume $V_{\mathrm{t}}$ (i.e., the inspired volume of air; Withers 1992) as $840 \mathrm{~mL}$ (see estimation in Appendix A6).

\subsubsection{Lung breathing rate required to meet $\mathrm{O}_{2}$ needs at SMR $20^{\circ} \mathrm{C}$ and AMR $25^{\circ} \mathrm{C}$}

Using the lung morphometric data and the partial pressure of oxygen $\left(\mathrm{pO}_{2}\right)$ in the early Permian atmosphere of $29 \mathrm{kPa}$, the breathing rate at SMR $20^{\circ} \mathrm{C}$ in the Archegosaurus model is estimated (see estimation in Appendix A7). The Archegosaurus model took about one breath every $20 \mathrm{~min}$ when resting at SMR and a little more than one breath every $5 \mathrm{~min}$ at $\mathrm{AMR} 25^{\circ} \mathrm{C}$ to meet its oxygen needs in hypoxic water. For comparison, Polypterus senegalus has a breathing rate of about one breath every $4 \mathrm{~min}$ when completely dependent on air breathing for $\mathrm{O}_{2}$ uptake in hypoxic water (Babiker, 1984, fig. 1).

\subsubsection{Estimation of hypothetical breathing rate for $\mathrm{CO}_{2}$ release via the lungs (as if gills were not present)}

The breathing rate for $\mathrm{CO}_{2}$ is estimated for the Archegosaurus model, with the lungs presupposed to be the only breathing organ (see estimation in Appendix A8). When only lung breathing is presupposed, it took the Archegosaurus model about one breath every 2 min to eliminate $\mathrm{CO}_{2}$ at rest and almost two breaths per minute during activity at $25^{\circ} \mathrm{C}$. For comparison, the garfish Lepisosteus osseus, which breathes water at low temperatures via its gills and becomes an obligate air breather as metabolic rate and ambient water temperature increase, has to come to the surface only every 4 to $9 \mathrm{~min}$ to gulp air at $25^{\circ} \mathrm{C}$ (Rahn et al., 1971). Although these values refer to $\mathrm{O}_{2}$ uptake of Lepisosteus $\left(\mathrm{CO}_{2}\right.$ is always eliminated via the gills), they show that the values estimated for the Archegosaurus model without gills would imply that it had to break through the water surface unusually often for an aquatic animal. Among several fish species that breathe with lungs or a gas bladder, no breathing rate higher than 20 breaths per hour has been 
observed (Graham, 1997, table 5.2). Therefore, it is unlikely that Archegosaurus took 120 breaths per hour and much more probable that Archegosaurus eliminated the bulk of metabolic $\mathrm{CO}_{2}$ via gills rather than via the lungs.

\subsection{Gill surface area in the Archegosaurus model}

Archegosaurus is considered here as a facultative air breather whose adult internal gills were able to supply the animal with the necessary amount of oxygen in well-aerated water at rest. Therefore, the surface area of the internal gills in the Archegosaurus model can be estimated based on the oxygen consumption rate at SMR estimated above as $5280 \mathrm{~cm}^{2}$ or $0.75 \mathrm{~cm}^{2} \mathrm{~g}^{-1}$ (see estimation in Appendix A9).

To our knowledge, no data concerning the surface area of polypterid fishes are available, but they can be compared to other extant air-breathing fishes. The value for the Archegosaurus model is smaller than that of the facultative air breather Amia with $1.95 \mathrm{~cm}^{2} \mathrm{~g}^{-1}$ (Daxboeck et al., 1981) but slightly larger than that of Lepisosteus osseus with $0.59 \mathrm{~cm}^{2} \mathrm{~g}^{-1}$ (Landolt and Hill, 1975), which is also a facultative air breather. The value is much larger than that for obligatory air-breathing teleosts like Anabas testudineus with $0.39 \mathrm{~cm}^{2} \mathrm{~g}^{-1}$ and Clarias mossambicus with $0.17 \mathrm{~cm}^{2} \mathrm{~g}^{-1}$ (Graham, 1997, p. 116), and especially the lepidosirenid lungfish Lepidosiren with only $0.00065 \mathrm{~cm}^{2} \mathrm{~g}^{-1}$ (de Moraes et al., 2005).

\section{Feeding and digestion}

\subsection{Food capture}

Archegosaurus was a piscivorous temnospondyl with a gharial-like "fish-eater snout". Intestine fillings of numerous specimens clearly show that it preyed preferentially on the acanthodian Acanthodes, whereas remains of the actinopterygian Paramblypterus within the stomach are exceptional (Boy, 1994; Witzmann, 2004a).

Most fishes and aquatic extant amphibians use suction during aquatic feeding. However, suction feeding was likely not possible in adult Archegosaurus with its elongate, narrow rostrum. Rather, it may have performed a lateral strike towards its prey, as performed by long-snouted crocodilians, gharials, and the actinopterygian Lepisosteus, for instance (Lauder and Norton, 1980; Cleuren and De Vree, 2000). The ossified basibranchial probably supported the buccal floor with the presumably simple tongue pad; therefore, it had to be a robust element because it was elevated during feeding to press the prey item against the toothed palate to fix and kill the prey. After killing, the prey had to be repositioned before swallowing, analogous to Lepisosteus (Lauder and Norton, 1980) and extant crocodilians (Cleuren and De Vree, 2000). A unidirectional flow of water in the buccal cavity and pharynx, from the mouth opening towards the gill slits, may have aided in transport of the prey. Furthermore, the large interpterygoid vacuities (Fig. 5) that were covered by small, dentigerous bony platelets in Archegosaurus indicate that the eyeballs were involved in the intrabuccal transport and swallowing by retraction into the mouth cavity, as reported in extant anurans (Levine et al., 2004) and salamanders (Deban and Wake, 2000). The branchial teeth on the ceratobranchials precluded the escape of prey through the gill slits (Witzmann, 2004b). Prey was probably swallowed whole, as in extant amphibians and Lepisosteus (Lauder and Norton, 1980).

\subsection{Food content}

The content of the food of Archegosaurus - mainly the acanthodian Acanthodes - can only very roughly be estimated because acanthodians are a long-extinct group of fishes whose phylogenetic position is still a matter of controversy (Brazeau and Friedman, 2015, and references therein). Initially regarded as the sister group of osteichthyans or their stem forms, acanthodians turned out to be a paraphyletic group of stem chondrichthyans in a recent phylogenetic analysis (Zhu et al., 2013). Therefore, the nutrition data of raw shark meat are taken as a rough approximation for the food content of Acanthodes to estimate the overall energy density of the food of the Archegosaurus model as $5.5 \mathrm{~kJ} \mathrm{~g}^{-1}$ (see estimation in Appendix A10).

\subsection{Digestion}

Absorption in the Archegosaurus model can be estimated based on the average daily metabolic rate estimated above (see estimation in Appendix A11). Per day, $0.08 \mathrm{~kg}$ of food has to be assimilated, with $0.006 \mathrm{~mol}$ of protein per day and $0.02 \mathrm{~mol}$ of fat per day. The kilograms of food per day that the Archegosaurus model had to consume to assimilate $0.08 \mathrm{~kg}$ can be estimated as $0.1 \mathrm{~kg}$ of food per day, meaning that more than six middle-sized acanthodians had to be consumed per day (see estimation in Appendix A12).

\section{Osmoregulation and excretion}

As described above, the paleoenvironment of Archegosaurus is interpreted as a large freshwater lake (Fischer et al., 2013; Schoch, 2014). Therefore, it can be assumed that Archegosaurus was hyperosmotic and hyperionic with respect to the ambient water. The osmolarity of the body fluids of Archegosaurus may have been similar to the polypterid $\mathrm{Er}$ petoichthys with a value of $200 \mathrm{mOsm} \mathrm{L}^{-1}$ (Lutz, 1975) and anurans with a value of $210 \mathrm{mOsm} \mathrm{L}^{-1}$ (Mayer, 1969); therefore, a value of $205 \mathrm{mOsm} \mathrm{L}^{-1}$ is set for the Archegosaurus model, and the osmolarity of the ambient freshwater is set as $50 \mathrm{mOsm} \mathrm{L}^{-1}$ (Martinez-Palacios et al., 2008). Similar to most freshwater fishes, Archegosaurus can be regarded as an osmoregulator and ionoregulator because osmolarity and ionic composition of body fluids were different from the osmolarity of the ambient water. Because Archegosaurus was 


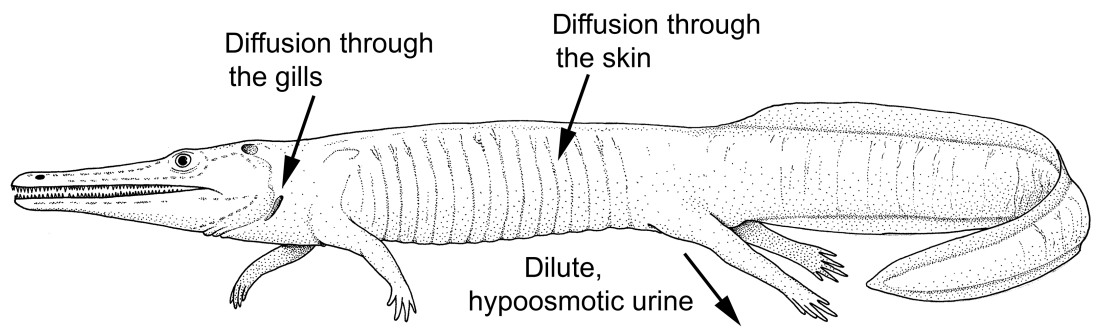

Figure 6. Water balance of the Archegosaurus model. Like extant freshwater fishes, Archegosaurus was probably hyperosmotic to its environment and gained water by diffusion through the skin and the gills; the osmotic influx of water had to be compensated for by the production of dilute, hypoosmotic urine by the kidneys.

probably hyperosmotic to the surrounding water, it gained water by diffusion through the skin and the gills (Fig. 6). Similar to extant freshwater fishes and extant aquatic amphibians, it can be assumed that the kidneys produced dilute, hypoosmotic urine (Withers, 1992). In this way, the osmotic influx of water through the gills and the skin was compensated.

\subsection{Water balance of Archegosaurus model}

In the Archegosaurus model, which is regarded here as hyperosmotic, $173 \mathrm{~g}$ of water per day were gained by osmosis through skin and gills (see estimation in Appendix A13).

\subsection{Ammonia and urine excretion}

Most fishes (including basal actinopterygians like polypterids) and amphibian larvae are ammonotelic animals, i.e., ammonia $\left(\mathrm{NH}_{3}\right.$ or $\left.\mathrm{NH}_{4}^{+}\right)$is the main end product of their nitrogen metabolism (Withers, 1992; Hillman et al., 2009). Exceptions are elasmobranchs, coelacanths, and estivating lepidosirenid lungfishes that excrete urea, similar to terrestrial amphibians and mammals (Wright, 2007). Ammonia is formed by the liver and kidney and is excreted down along the blood-to-water partial pressure gradient through the gills, which are usually the dominant excretion site of nitrogenous waste products in actinopterygians; this diffusional route dominates nitrogen excretion by the kidneys (as urine) and via the skin (Wright, 2007). In aquatic amphibians like Necturus or Typhlonectes, nitrogen excretion via the kidneys is also normally low (Hillman et al., 2009). Thus, it can be assumed that the main nitrogen excretory form in the largely aquatic Archegosaurus was ammonia, and the major excretion site was the internal gills.

No data concerning the relative amount of ammonia and urea in nitrogen excretion of polypterids are available. However, in other basal actinopterygians like Acipenser (in freshwater) and Amia, 7-12\% of nitrogen is eliminated as urea (Wright, 2007, table 6.1). For the Archegosaurus model, we take a value of $10 \%$, and thus $90 \%$ of the ammonia nitrogen is eliminated by the gills. The amount of urea that was ex- creted per day in the Archegosaurus model can be estimated as $0.018 \mathrm{~mol}$ (see estimation in Appendix 14).

\subsection{Solute balance of the Archegosaurus model}

Because Archegosaurus was hyperosmotic and hyperionic to the ambient water like extant freshwater fishes, it must have lost ions by diffusion through the skin and the gills (Fig. 7). To retain a constant osmolarity of its body fluids, ions (mainly $\mathrm{Na}^{+}$and $\mathrm{Cl}^{-}$) were probably actively taken up from the surrounding water via chloride cells in the gills. It can be assumed that a loss of potassium ions $\left(\mathrm{K}^{+}\right)$occurred via the gills, as was demonstrated in extant freshwater teleosts (Gardaire and Isaia, 1992), and via the kidneys (Fig. 7); this loss was compensated for by absorption of potassium from the food.

The loss and uptake of $\mathrm{Na}^{+}$and $\mathrm{Cl}^{-}$in the Archegosaurus model are estimated (see estimation in Appendix 15). According to these estimations, the Archegosaurus model is able to compensate for the loss of these ions via gills, skin, and urine $\left(198 \mathrm{mmol} \mathrm{day}^{-1}\right)$ by their active uptake through the gills and via ingestion of food $\left(218 \mathrm{mmol} \mathrm{day}^{-1}\right)$.

\section{Discussion}

\subsection{Synthesizing the results}

Physiology of an animal does not fossilize, and therefore our approach to reconstructing physiological aspects of Archegosaurus is based on (1) direct observations at fossil skeletons and identification of osteological correlates of physiologically relevant soft-tissue organs since these organs (e.g., gills and lungs) are only directly preserved in fossils in exceptional cases and (2) comparison with extant animals. Although Archegosaurus is phylogenetically more closely related with extant amphibians (lissamphibians) than with osteichthyan fishes, lissamphibians are not appropriate analogs for the physiology of Archegosaurus because most of them have a much smaller size and body mass, and salamanders have an unusually low metabolic rate. Furthermore, lissamphibians are highly derived in the possession 


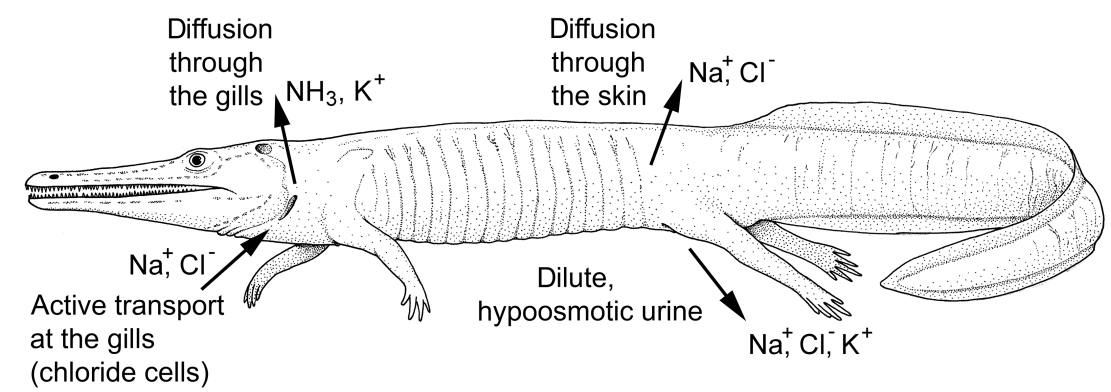

Figure 7. Solute balance of the Archegosaurus model. Because Archegosaurus was probably hyperosmotic and hyperionic to its environment, it lost ions by diffusion through the gills similar to freshwater fishes. It can be assumed that specialized chloride cells were present in the gills that actively took up ions (mainly $\mathrm{Na}^{+}$and $\mathrm{Cl}^{-}$) from the ambient water to retain a constant osmolarity of the body fluids.

of a thin, naked skin that is well vascularized and capable of large-scale cutaneous respiration (Duellman and Trueb, 1994). In contrast, Archegosaurus is more similar to osteichthyan fishes than to lissamphibians in possessing internal gills and ossified dermal scales that covered the body. For these reasons, we compared Archegosaurus mainly with airbreathing fishes (especially polypterids) and to a lesser degree with lissamphibians. This comparison may yield qualitative information (e.g., how the gills are used for $\mathrm{O}_{2}$ uptake and $\mathrm{CO}_{2}$ loss and how they are ventilated) as well as quantitative guesses, i.e., modeling of the physiology of the fossil animal under study dependent on the physical principles of life processes, such as the relationship between body mass and metabolic rate. It was our aim to show that the particular physiological mechanisms were interconnected with each other in the Archegosaurus model and quantitatively interdependent (Fig. 8).

The first step was the estimation of body mass based on a skeletal reconstruction and by graphic double integration (Fig. 8). This laid the foundation for almost all further theoretical estimations, and therefore special care was required in reconstructing the skeleton and the body outline. This step was based mainly on fossil evidence (the preserved skeleton) and to a lesser degree on assumptions based on extant analogs (drawing of body outline and assumption of specific gravity).

The second step was the assessment of SMR dependent on the estimated body mass. This was completely carried out by comparison with modern analogs, and there is undoubtedly a large source of error in the choice of the best metabolic rate: even when body mass is given, metabolic rate may be variable between different individuals of a group (as shown in Fig. 3 in Heusner, 1982 for different species of mammals, for example). Therefore, there are not only multiple sources of error concerning the estimation of body mass of a fossil tetrapod but also in assessment of metabolic rate when the mass and the taxon that serves as an extant analog are given. We started our physiological estimation for the Archegosaurus model with metabolic rates given for different salamanders
(Withers, 1992), but the resulting metabolic values were unrealistically low. This falsified our first assumptions that temnospondyls like Archegosaurus could be best compared to salamanders in terms of their physiology. The low values can be attributed to the exceptionally low metabolism of salamanders, which is in fact the lowest of all extant tetrapods (Licht and Lowcock, 1991). It can also be attributed to the fact that maximum body size and mass in most salamanders (and all frogs and caecilians) is well below the value for temnospondyls like Archegosaurus. An exception in respect of size and mass is the giant salamanders of the genera Cryptobranchus and Andrias that reach maximum sizes of 70 to $150 \mathrm{~cm}$, but these animals are highly derived in respect of their respiratory physiology (Ultsch, 2012) and like other salamanders have a low metabolic rate (Licht and Lowcock, 1991). Therefore, and because of similarities like the presence of internal gills, we chose a metabolic rate given for fishes rather than for salamanders (Withers, 1992) to estimate the SMR for the Archegosaurus model (Fig. 8). The subsequent estimation of AMR and ADMR were dependent on the ambient water temperature of Lake Humberg in which Archegosaurus lived. Therefore, the temperature in the surface layers of this fossil lake was estimated based on (1) direct geological evidence (paleolatitude of the lake close to the equator and its altitude in the early Permian) and (2) in analogy with an extant lake in a comparable climatic region and altitude. Estimations of SMR, AMR, and ADMR were the prerequisites for many of the subsequent estimations (Fig. 8). For reconstruction of the mode of breathing in Archegosaurus, the finding that adult specimens possessed fish-like internal gills was most important. This is derived from fossil evidence (the presence of branchial teeth) and the phylogenetic position of Archegosaurus (with closely related temnospondyls showing osteological correlates of internal gills). Direct fossil preservation of larval external gills and comparison with living vertebrates that develop larval external gills suggest that Archegosaurus had reduced its internal gills to a certain degree and relied on aerial respiration for $\mathrm{O}_{2}$ uptake as an adult in hypoxic water and in times 


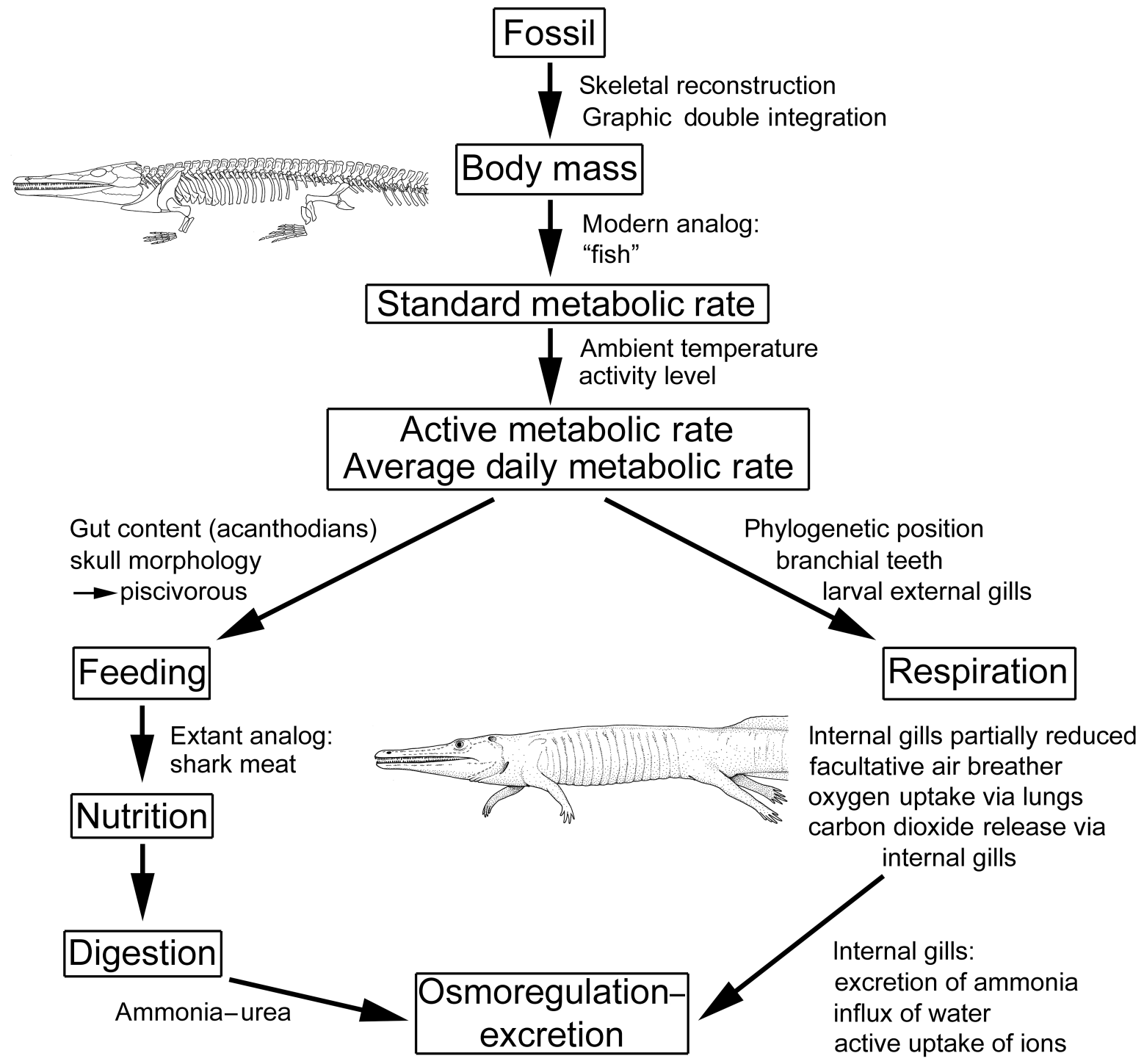

Figure 8. Synthesizing data and modeling from many sources. Graphic summary of the physiological reconstructions of the present study for Archegosaurus decheni considering the information provided by osteological correlates (i.e., information provided directly by the fossils) and theoretical estimations based on the physiology of extant analogs. The particular results like body mass, metabolic rate, feeding (inclusive nutrition and digestion) and respiration are mutually dependent.

of activity. With these prerequisites, estimation of breathing rate for $\mathrm{CO}_{2}$ elimination suggests that if the internal gills were not present, Archegosaurus would have had to ventilate its lungs to an extent that would have been unusual for an aquatic animal. Alternatively, it would imply a highly derived respiratory physiology, as seen in the extant lungfish Lepidosiren (see Sect. 5.2.1). The presence of internal gills in adult Archegosaurus is not only important for the attempt to reconstruct the mode of breathing in this temnospondyl, it is also crucial for our understanding of its mode of osmoregulation and excretion (Fig. 8) since gill-bearing and non-gill-bearing vertebrates differ in their water and solute balance. Like freshwater fishes, Archegosaurus had to cope with osmotic influx of water through the gills and had to compensate for this by production of dilute, hypoosmotic urine by the kidneys. Furthermore, chloride cells in the gills may have helped to retain a constant osmolarity of the body fluids by active uptake of ions from the surrounding water (Withers, 1992). In contrast to this, feeding and digestion of Archegosaurus is independent from reconstruction of this animal with or without gills as an adult. The fossils showing the fortunate combination of well-preserved snout morphology, dentition, and numerous gut contents make the reconstruction of Archegosaurus as a piscivorous animal specialized 
on Acanthodes unequivocal. However, aspects of digestion that were estimated above (protein absorption) were prerequisites for the estimation of ammonia-urine excretion in the Archegosaurus model (Fig. 8).

\subsection{The perception of Archegosaurus through time: from an early reptile to a salamander-like animal to a "fish with four legs"}

Archegosaurus decheni has been known to the scientific world since its original description by Goldfuss (1847). In the first comprehensive monographs of this taxon, Archegosaurus was attributed to reptiles rather than to amphibians (von Meyer, 1854, 1858), and this assignment was certainly influenced by the outline of the skull that is so characteristic for gharials and long-snouted crocodilians rather than for lissamphibians. However, this view was already disputed by contemporary scientists like Vogt (1854), who classified Archegosaurus as an amphibian based on the structure of its vertebral column. Vogt was supported by Owen (1861, p. 202), who regarded Archegosaurus as a "transitional form between the batrachians and the ganoids". At least since the 1890s it has been universally accepted that Archegosaurus (and temnospondyls in general) are amphibians in the broader sense, i.e., anamniotic tetrapods. In analogy with extant lissamphibians, Archegosaurus had been reconstructed as a salamander-like animal that was derived from more terrestrial ancestors and was thus secondary aquatic (Schoch and Milner, 2000; Witzmann and Schoch, 2006). During its ontogeny, a phase of metamorphosis was assumed in which Archegosaurus reduced its larval external gills and relied completely on lung breathing (Boy, 1974; Boy and Sues, 2000). In our model, which is based on new results concerning the breathing modes of temnospondyls (Schoch and Witzmann, 2011; Witzmann, 2013, 2016), Archegosaurus was a primarily aquatic animal throughout its life history, and in contrast to extant aquatic lissamphibians, it was not derived from a more terrestrial ancestor. Rather, Archegosaurus is reconstructed here as an animal that possessed internal gills as an adult as a direct heritage from its fish-like ancestors. Analogous to polypterid actinopterygians, we assume that the internal gills of Archegosaurus were slightly reduced, as indicated by the presence of larval external gills that served as accessory water-breathing organs until the lungs were fully functional. This hypothesized slight reduction might be connected with sporadic terrestrial sojourns of Archegosaurus, which can also be observed in polypterids (Sacca and Burggren, 1982; Pettit and Beitinger, 1985; Graham, 1997; Bartsch, 2004; Pace and Gibb, 2011; Standen et al., 2014; Du et al., 2016). The assumption of the presence of internal gills in Archegosaurus is supported by the rather unrealistically high breathing rate estimated in this study when presupposed that the Archegosaurus model had to rely solely on its lungs for $\mathrm{CO}_{2}$ elimination. Thus, the physiology of the Archegosaurus model is much more simi- lar to that of air-breathing fishes than to that of lissamphibians, and this probably holds true for the majority of temnospondyls. The temnospondyls that can probably best be compared with lissamphibians are the mostly small-growing dissorophoids (Fig. 1) that have a salamander-like habitus and constitute the presumed stem group of lissamphibians (Schoch, 2014). Dissorophoids are derived in having completely reduced the ancestral internal gills and were clearly adapted to a terrestrial lifestyle as adults (Witzmann, 2016).

\section{Data availability}

This is not applicable because there are no data sets/research data that could be deposited. All methods and data on which this study is based on are provided in the text and appendix. 


\section{Appendix A}

All estimations mentioned in the main text are shown below.

\section{A1 Estimation of body volume and body mass by graphic double integration (GDI)}

Using Adobe Photoshop CS6, 62 vertical lines were drawn across the lateral outline of the axial body (i.e., 62 slices through the body), each separated by a distance of $2 \mathrm{~cm}$ (Fig. 3a, b). In the same locations, 62 transverse lines were drawn across the body outline in dorsal view. The vertical and transverse lines are perpendicular to each other and represent the vertical $\left(d_{\mathrm{v}}\right)$ and transverse diameter $\left(d_{\mathrm{t}}\right)$ of each of the 62 elliptical slices. The area $A_{\mathrm{e}}$ of each ellipse was calculated as

$A_{\mathrm{e}}=\pi d_{\mathrm{v}} d_{\mathrm{t}} / 4$

Then the average of the areas of the individual ellipses $\bar{A}_{\mathrm{e}}$ was calculated as $52.5 \mathrm{~cm}^{2}$ for the axial body. Multiplication of this value by body length $L$ yielded the volume $V_{\mathrm{ab}}$ of the elliptical cylinder representing the axial body:

$V_{\mathrm{ab}}=\bar{A}_{\mathrm{e}} L=52.5 \mathrm{~cm}^{2} \times 126 \mathrm{~cm}=6615 \mathrm{~cm}^{3}$.

The same method was used to estimate the volumes of the forelimbs $(\times 2)$ and the hind limbs $(\times 2)$. Fore- and hind limbs were drawn in lateral and dorsal view (Fig. 3c, d). In dorsal view, the individual fingers and toes were drawn as attached to each other to form a paddle. The outline of each forelimb has a length of $15.3 \mathrm{~cm}$, and 15 vertical and transverse lines were drawn across the lateral and dorsal outlines, respectively, separated by a distance of $1 \mathrm{~cm}$. The average area of the individual ellipses was then calculated as $4.5 \mathrm{~cm}^{2}$. Therefore, the volume of both forelimbs is $2 \times 4.5 \mathrm{~cm}^{2} \times$ $15.3 \mathrm{~cm}=138 \mathrm{~cm}^{3}$. The outline of the hind limbs has a length of $19.8 \mathrm{~cm}$, and the 19 elliptical slices were set in intervals of $1 \mathrm{~cm}$, as in the forelimbs. The average area of the ellipses is $5.2 \mathrm{~cm}^{2}$, and therefore the volume of both hind limbs is $2 \times 5.2 \mathrm{~cm}^{2} \times 19.8 \mathrm{~cm}=206 \mathrm{~cm}^{3}$. Accordingly, the total volume $(V)$ of the Archegosaurus reconstruction is $V=6615+138+206 \mathrm{~cm}^{3}=6959 \mathrm{~cm}^{3}$ or approximately $7 \mathrm{~L}$ $(V \approx 7 \mathrm{~L})$.

Body mass can be calculated from the product of volume and density $\rho$ (or specific gravity) of the body. Only very few values of specific densities of amphibians can be found in the literature. With values between 1.007 and 1.018 (William, 1900), the specific gravity of late larval stages of Bufo and Rana is only slightly above the density of water (value of 1), and a specific gravity between 1.01 and 1.08 has been reported for the terrestrial salamander Hynobius (Hasumi and Iwasawa, 1992). The specific gravity of an aquatic animal like Archegosaurus depends on the amount of air in the lungs. In times when the animal was floating at the surface or actively swimming, it may have relied on buoyancy provided by the lungs filled with air, and the specific gravity may have been slightly less than 1 . In contrast, when the animal was walking on the bottom or lurking submerged for prey, a value slightly larger than 1 would have been advantageous and most of the air was exhaled from the lungs. Therefore, we assume that the specific gravity of Archegosaurus corresponded largely with the density of water; thus, the body mass $\mathrm{M}$ of the Archegosaurus reconstruction is $\mathrm{M}=$ $V \rho=7 \mathrm{~L} \times 1 \mathrm{~kg} \mathrm{~L}^{-1}=7 \mathrm{~kg}$.

It must be emphasized here, however, that this value is an estimate with several sources of errors that can be attributed to potential mistakes in the skeletal reconstruction (due to incompleteness of the fossils, distortion of skeletal elements, incorrect reconstruction of the amount of soft tissue covering the skeleton, or inadequate specific gravity assumed), for example. We estimate that the volume calculation may be incorrect by at most $1 \mathrm{~L}$ either way, meaning the mass may have been 6 to $8 \mathrm{~kg}$. This range requires notably thin (for $6 \mathrm{~kg}$ ) or robust (for $8 \mathrm{~kg}$ ) reconstructions, to the point that they look unlikely. Hence, $6-8 \mathrm{~kg}$ is a conservative range and will be used in the following as the basis for physiological estimations.

\section{A2 Estimation of body surface area of the Archegosaurus model}

Head, trunk, and tail (without fin) are subdivided into 63 elliptical cylinders of $2 \mathrm{~cm}$ length (see Appendix A1). The perimeter $P$ of each respective ellipse was calculated using the following equation (given in Hurlburt, 1999, for example): $P=2 \pi\left[(0.5)\left(d_{\mathrm{v}}^{2}+d_{\mathrm{t}}^{2}\right)\right]^{0.5}$, again with $d_{\mathrm{v}}$ being the vertical and $d_{\mathrm{t}}$ being the transverse diameter of the ellipse. Multiplication of each perimeter by the length of $2 \mathrm{~cm}$ yielded the respective surface area; addition of the surfaces of all cylinders yielded the surface area of head, trunk, and tail (without fin) of approximately $3001 \mathrm{~cm}^{2}$.

Surface areas of fore- and hind limbs were calculated in the same way; the surface area of both forelimbs is $239 \mathrm{~cm}^{2}$ and of both hind limbs is $322 \mathrm{~cm}^{2}$

The surface area of the fin was estimated by fitting 14 rectangles in the dorsal fin and 13 rectangles in the ventral fin. The area of each rectangle was calculated, the areas summated and multiplied by 2 (left and right surface of the fin). This method yielded a surface area of the fin of $389 \mathrm{~cm}^{2}$.

Thus, the total body surface area of the Archegosaurus model can be estimated as $3001 \mathrm{~cm}^{2}+239 \mathrm{~cm}^{2}+322 \mathrm{~cm}^{2}+$ $382 \mathrm{~cm}^{2} \approx 4000 \mathrm{~cm}^{2}$.

\section{A3 Estimation of standard and active metabolic rate at $20^{\circ} \mathrm{C}$}

The range of body temperatures of Archegosaurus might have been between 10 and $30^{\circ} \mathrm{C}$, in analogy with extant cryptobranchids, amphiumids, and sirenids that are all aquatic, large-growing salamanders (mean $20.1^{\circ} \mathrm{C}$; Duell- 
man and Trueb, 1994, p. 210). The extant Australian lungfish Neoceratodus has the same range of body temperatures $\left(10-30{ }^{\circ} \mathrm{C}\right.$, mean $19.9{ }^{\circ} \mathrm{C}$; Pusey et al., 2004). Thus, the assumption for the following estimations is that the body temperature $T_{\mathrm{b}}$ of Archegosaurus was equal to the ambient temperature of the water $T_{\mathrm{a}}: T_{\mathrm{b}}=T_{\mathrm{a}}$. Taking the allometric formula for the metabolic rate of fishes (see Sect. 4) $E_{\text {metab }}=$ $4.8 \mathrm{M}^{0.88}$ (for $20^{\circ} \mathrm{C}$ ) and the estimated body mass for an adult Archegosaurus of $7000 \mathrm{~g}$, the standard metabolic rate (i.e., rate of a resting animal) at $20^{\circ} \mathrm{C}\left(\mathrm{SMR} 20^{\circ} \mathrm{C}\right)$ can be estimated as $4.8 \times 7000^{0.88}=11.6 \mathrm{~kJ} \mathrm{~h}^{-1} \approx 12 \mathrm{~kJ} \mathrm{~h}^{-1}$.

This estimate includes potential error in body mass and error resulting from uncertainty in the allometric curve for metabolic rate of fishes. Using 6000 and $8000 \mathrm{~g}$ ranges of body masses yields a range of $10.1-13.1 \mathrm{~kJ} \mathrm{~h}^{-1}$. However, use of an alternate scaling relationship for all fishes, $E_{\text {metab }}=$ $2.5 \mathrm{M}^{0.70}$, yields a standard metabolic rate 10 times lower for a $7 \mathrm{~kg}$ Archegosaurus, $\approx 1.2 \mathrm{~kJ} \mathrm{~h}^{-1}$.

AMR in fishes is typically 1.6 to 3.8 times the costs connected with SMR (Boisclair and Sirois, 1993). Therefore, it is assumed here that the active metabolic rate at $20^{\circ} \mathrm{C}$ (AMR $20^{\circ} \mathrm{C}$ ) was 2.5 times SMR $20^{\circ} \mathrm{C}$ in Archegosaurus and can be estimated as $2.5 \times 12 \mathrm{~kJ} \mathrm{~h}^{-1}=30 \mathrm{~kJ} \mathrm{~h}^{-1}$.

\section{A4 Estimation of increasing active metabolic rate at higher temperature}

AMR at $25^{\circ} \mathrm{C}\left(R_{2}\right)$ is estimated in the following, with $R_{1}$ being AMR $20^{\circ} \mathrm{C}$ (see Sect. 4.1), $T_{2}=25^{\circ} \mathrm{C}, T_{1}=20^{\circ} \mathrm{C}$, and $Q_{10}=2.5$, i.e., all metabolic processes increase by a factor of 2.5 with a $10^{\circ} \mathrm{C}$ increase in body temperature:

$$
\begin{aligned}
& \operatorname{AMR} 25^{\circ} \mathrm{C}=R_{2}=R_{1}\left(Q_{10}\right)^{(T 2-T 1 / 10)} \\
& =\left(30 \mathrm{~kJ} \mathrm{~h}^{-1}\right)(2.5)^{(25-20 / 10)}=47 \mathrm{~kJ} \mathrm{~h}^{-1} .
\end{aligned}
$$

\section{A5 Estimation of average daily metabolic rate (ADMR)}

It is assumed here that Archegosaurus was active for $4.5 \mathrm{~h}$ per day (see main text).

$$
\begin{aligned}
& \mathrm{ADMR}=\left[\left(4.5 \mathrm{~h} \times \mathrm{AMR} \text { at } 25^{\circ} \mathrm{C}\right)+(19.5 \mathrm{~h}\right. \\
& \left.\left.\times \mathrm{SMR} \text { at } 20^{\circ} \mathrm{C}\right)\right] / 24 \mathrm{~h}=\left[\left(4.5 \mathrm{~h} \times 47 \mathrm{~kJ} \mathrm{~h}^{-1}\right)\right. \\
& \left.+\left(19.5 \mathrm{~h} \times 12 \mathrm{~kJ} \mathrm{~h}^{-1}\right)\right] / 24 \mathrm{~h}=18.5 \mathrm{~kJ} \mathrm{~h}^{-1} \approx 19 \mathrm{~kJ} \mathrm{~h}^{-1}
\end{aligned}
$$

\section{A6 Estimation of lung morphometric data of Archegosaurus based on Polypterus senegalus}

Lung volume $\mathbf{V}_{\mathbf{L}}$. Lung volume in Polypterus senegalus is about $20 \%$ of body volume (Brainerd, 1994). For the Archegosaurus model with a body volume of $7000 \mathrm{~mL}$, the lung volume can be estimated as $V_{\mathrm{L}}=1400 \mathrm{~mL}$.

Tidal volume $\mathbf{V}_{\mathbf{t}}$. Tidal volume for Polypterus senegalus is $60 \%$ of lung volume (Magid et al., 1970); thus, tidal volume in the Archegosaurus model is $V_{\mathrm{t}}=840 \mathrm{~mL}$ air per breath.

\section{A7 Estimation of air-breathing rate required to meet $\mathrm{O}_{2}$ needs at SMR $20^{\circ} \mathrm{C}$ and $\mathrm{AMR} 25^{\circ} \mathrm{C}$, if all oxygen is obtained from the air (as in hypoxic water)}

For these estimations, lung volume $V_{\mathrm{L}}=1400 \mathrm{~mL}$ and tidal volume $V_{\mathrm{t}}=840 \mathrm{~mL}$ are given. The partial pressure of oxygen in fresh air $\left(p \mathrm{O}_{2}\right)$ is set as $29 \mathrm{kPa}$ in the early Permian atmosphere, and the partial pressure of exhaled air $\left(p \mathrm{O}_{2 \mathrm{ex}}\right)$ is $5.7 \mathrm{kPa}$ in Polypterus senegalus (based on the mean values of left and right lungs in Magid et al., 1970, table 1). According to the early Permian atmospheric conditions, we extrapolated $p \mathrm{O}_{2 \mathrm{ex}}$ in Archegosaurus as $7.8 \mathrm{kPa}$.

Breathing rate at SMR $20^{\circ} \mathrm{C}$. SMR $20^{\circ} \mathrm{C}$ in Archegosaurus model is $12 \mathrm{~kJ} \mathrm{~h}^{-1}$ (see above). The rate of oxygen consumption $V_{\mathrm{O}_{2}}$ at $\mathrm{SMR}\left(20^{\circ} \mathrm{C}\right)$ in $\mathrm{mL} \mathrm{O}_{2} \mathrm{~min}^{-1}$ can be estimated as follows:

$$
\begin{aligned}
& V_{\mathrm{O}_{2}}=\left(12 \mathrm{~kJ} \mathrm{~h}^{-1}\right) /\left(20 \mathrm{kJL}^{-1} \mathrm{O}_{2}\right)=0.6 \mathrm{LO}_{2} \mathrm{~h}^{-1} \\
& =600 \mathrm{mLO}_{2} \mathrm{~h}^{-1} \times(1 \mathrm{~h} / 60 \mathrm{~min})=10 \mathrm{mLO}_{2} \mathrm{~min}^{-1} .
\end{aligned}
$$

The minute volume $V_{\mathrm{E}}$ in millimeters of air per minute required to sustain this rate of oxygen consumption can be estimated as follows:

$$
\begin{aligned}
& V_{\mathrm{O}_{2}}=V_{\mathrm{E}}\left(p \mathrm{O}_{2 \mathrm{in}}-p \mathrm{O}_{2 \mathrm{ex}}\right) / 100 \mathrm{kPa} \\
& 10 \mathrm{mLO}_{2} \min ^{-1}=V_{\mathrm{E}}(29-7.8 \mathrm{kPa}) / 100 \mathrm{kPa} \\
& \rightarrow V_{\mathrm{E}}=47 \mathrm{~mL} \text { air } \min ^{-1} .
\end{aligned}
$$

Thus, the resting breathing rate at $\mathrm{SMR} 20^{\circ} \mathrm{C}$ is $\mathrm{BR}_{\mathrm{SMR}}=V_{\mathrm{E}} / V_{\mathrm{t}}=47 / 840=0.05$ breaths per minute or about one breath every $20 \mathrm{~min}$.

Breathing rate at AMR $25^{\circ} \mathrm{C}$. AMR $25^{\circ} \mathrm{C}\left(R_{2}\right)$ in the Archegosaurus model is $47 \mathrm{~kJ} \mathrm{~h}^{-1}$ (see Sect. 4.2). The rate of oxygen consumption $V_{\mathrm{O}_{2}}$ at $\mathrm{AMR}\left(25^{\circ} \mathrm{C}\right)$ in millimeter of $\mathrm{O}_{2}$ per minute can be estimated as follows:

$V_{\mathrm{O}_{2}}=2.4 \mathrm{~L} \mathrm{O}_{2} \mathrm{~h}^{-1}=40 \mathrm{mLO}_{2} \min$.

The minute volume $V_{\mathrm{E}}$ in liters of air per minute can be estimated as follows:

$$
\begin{aligned}
& V_{\mathrm{O}_{2}}=V_{\mathrm{E}}\left(p \mathrm{O}_{2 \mathrm{in}}-p \mathrm{O}_{2 \mathrm{ex}}\right) / 100 \mathrm{kPa} \\
& 40 \mathrm{mLO}_{2} \min ^{-1}=V_{\mathrm{E}}(29-7.8 \mathrm{kPa}) / 100 \mathrm{kPa} \\
& \rightarrow V_{\mathrm{E}}=189 \mathrm{~mL} \text { air min }
\end{aligned}
$$

Thus, the breathing rate at $\mathrm{AMR} 25^{\circ} \mathrm{C}$ is $\mathrm{BR}_{\mathrm{AMR}} 25^{\circ} \mathrm{C}=$ $V_{\mathrm{E}} / V_{\mathrm{t}}=189 \mathrm{~mL} / 840 \mathrm{~mL}=0.23$ breaths per minute or about one breath every $5 \mathrm{~min}$. 
A8 Estimation of hypothetical breathing rate for $\mathrm{CO}_{2}$ release via the lungs (as if gills were not present in the Archegosaurus model)

The respiratory quotient (RQ) is defined as the ratio of volume $\mathrm{CO}_{2}$ produced per $\mathrm{O}_{2}$ consumed (Withers, 1992), i.e., $V_{\mathrm{CO}_{2}} / V_{\mathrm{O}_{2}}$. For carbohydrate metabolism, RQ is 1 , for lipids it is approximately 0.7 , and for protein it is approximately 0.84 (Withers, 1992). In the following, we use the RQ for protein because Archegosaurus fed predominantly on fish (see main text).

Therefore, we assume $V_{\mathrm{CO}_{2}}=0.84 V_{\mathrm{O}_{2}}$ for the Archegosaurus model. The partial pressure of carbon dioxide in exhaled air from Polypterus senegalus is approximately $p \mathrm{CO}_{2 \mathrm{ex}}=2.2 \mathrm{kPa}$ (we took the mean values of left and right lungs in Magid et al., 1970, table 1). The partial pressure of carbon dioxide in inhaled air $\left(p \mathrm{CO}_{2 \text { in }}\right)$ is taken to be $0.047 \mathrm{kPa}$ for the early Permian atmosphere (see Sect. 2).

Breathing rate at SMR $20^{\circ}$ C. $\quad V_{\mathrm{CO}_{2}}=0.84 V_{\mathrm{O}_{2}}=$ $(0.84)\left(10 \mathrm{~mL} \mathrm{O}_{2} \mathrm{~min}^{-1}\right)=8.4 \mathrm{mLCO}_{2} \mathrm{~min}^{-1}$,

$V_{\mathrm{CO}_{2}}=V_{\mathrm{E}}\left(p \mathrm{CO}_{2 \mathrm{ex}}-p \mathrm{CO}_{2 \mathrm{in}}\right) / 100 \mathrm{kPa}$

$8.4 \mathrm{mLCO}_{2} \mathrm{~min}^{-1}=V_{\mathrm{E}}(2.2-0.047 \mathrm{kPa}) / 100 \mathrm{kPa}$

Minute volume $V_{\mathrm{E}}=376 \mathrm{~mL}$ air per minute at SMR.

Breathing rate $(\mathrm{BR})$ at $\mathrm{SMR}=V_{\mathrm{E}} / V_{\mathrm{t}}=390 \mathrm{~mL} / 840 \mathrm{~mL}$ $=0.5$ breaths per minute.

Breathing rate at $\mathbf{A M R} \quad 2^{\circ} \mathbf{C} . \quad V_{\mathrm{CO}_{2}}=0.84 V_{\mathrm{O}_{2}}=$ $(0.84)\left(40 \mathrm{~mL} \mathrm{O}_{2} \min ^{-1}\right)=34 \mathrm{~mL} \mathrm{CO}_{2} \min ^{-1}$,

$V_{\mathrm{CO}_{2}}=V_{\mathrm{E}}\left(p \mathrm{CO}_{2 \mathrm{ex}}-p \mathrm{CO}_{2 \mathrm{in}}\right) / 100 \mathrm{kPa}$

$34 \mathrm{mLCO}_{2} \mathrm{~min}^{-1}=V_{\mathrm{E}}(2.2-0.047 \mathrm{kPa}) / 100 \mathrm{kPa}$

Minute volume $V_{\mathrm{E}}=1580 \mathrm{~mL}$ air per minute at $\mathrm{AMR} 25^{\circ} \mathrm{C}$.

$\mathrm{BR}$ at $\mathrm{AMR} 25^{\circ} \mathrm{C}=V_{\mathrm{E}} / V_{\mathrm{t}}=1486 \mathrm{~mL} / 840 \mathrm{~mL}=1.9$ breaths per minute $\approx 120$ breaths per hour.

\section{A9 Estimation of the gill surface area in the Archegosaurus model}

The gill surface area required to supply $V_{\mathrm{O}_{2}}$ at $\mathrm{SMR}\left(20^{\circ} \mathrm{C}\right)$ in milliliters of $\mathrm{O}_{2}$ per minute can be estimated as follows:

$V_{\mathrm{O}_{2}}=D(\mathrm{SA} / X)\left(p_{\mathrm{w}} \mathrm{O}_{2}-p_{\mathrm{c}} \mathrm{O}_{2}\right) / 100 \mathrm{kPa}$.

$V_{\mathrm{O}_{2}}$ is $10 \mathrm{~mL} \mathrm{O}_{2} \mathrm{~min}^{-1}$ in the Archegosaurus model (see Appendix A7). SA is the gill surface area. $X$ is the diffusion distance of the water-blood barrier. In fish gills, $X$ ranges from 0.6 to $6 \mu \mathrm{m}$ (Withers, 1992, table 12-8); therefore, the mean of these values is taken here: $3.3 \mu \mathrm{m}=$ $3.3 \times 10^{-4} \mathrm{~cm} . D$ is the diffusion coefficient that is set here at about $10 \times 10^{-6} \mathrm{~cm}^{2} \mathrm{~s}^{-1}$; this estimation is based on Withers
(1992, table 12-6, value between human lung and eel skin). $p_{\mathrm{w}} \mathrm{O}_{2}-p_{\mathrm{c}} \mathrm{O}_{2}$ is the difference between the partial pressure of oxygen in the ambient water and in the capillaries during the time a body of water is in contact with the lamellae of the gills. Here we assume a value of $p_{\mathrm{w}} \mathrm{O}_{2}-p_{\mathrm{c}} \mathrm{O}_{2}=0.1 \mathrm{kPa}$ in the Archegosaurus model because in extant fishes the epithelium of the gill lamellae usually has a thickness of around $5 \mu \mathrm{m}$ (Heldmaier and Neuweiler, 2004) and no significant difference in concentration between blood and water can be expected.

The gill SA required for $V_{\mathrm{O}_{2}}=10 \mathrm{~mL} \mathrm{O}_{2} \mathrm{~min}^{-1}=$ $0.16 \mathrm{~mL} \mathrm{O}_{2} \mathrm{~s}^{-1}$ can be estimated as

$$
\begin{aligned}
V_{\mathrm{O}_{2}} & =D(\mathrm{SA} / X)\left(p_{\mathrm{w}} \mathrm{O}_{2}-p_{\mathrm{c}} \mathrm{O}_{2}\right) / 100 \mathrm{kPa} \\
\mathrm{SA} & =\left(V_{\mathrm{O}_{2}}\right)(X) /\left[D\left(p_{\mathrm{w}} \mathrm{O}_{2}-p_{\mathrm{c}} \mathrm{O}_{2}\right) / 100\right] \\
\mathrm{SA} & =\left(0.16 \mathrm{mLO}_{2} \mathrm{~s}^{-1}\right)\left(3.3 \times 10^{-4} \mathrm{~cm}\right) /\left(10 \times 10^{-6}\right)(0.001) \\
& =5280 \mathrm{~cm}^{2}
\end{aligned}
$$

for a specimen of Archegosaurus with a body mass of $7000 \mathrm{~g}$.

Therefore, the surface area of gills per gram in the Archegosaurus model is $5280 \mathrm{~cm}^{2} / 7000 \mathrm{~g}=0.75 \mathrm{~cm}^{2} \mathrm{~g}^{-1}$.

\section{A10 Estimation of food content}

For raw shark meat, $100 \mathrm{~g}$ (data from http://nutritiondata.self. com/facts/finfish-and-shellfish-products/4121/2) has the following content: $5 \mathrm{~g}$ total fat, $21 \mathrm{~g}$ protein, $0 \mathrm{~g}$ carbohydrate, and $74 \mathrm{~g}$ water. It is assumed here that $10 \%$ of the complete fish are indigestible (cartilage, scales), again $20 \%$ of which is water. Therefore, $1 \mathrm{~g}$ of shark contains $0.045 \mathrm{~g}$ total fat, $0.189 \mathrm{~g}$ protein, $0.686 \mathrm{~g}$ water, and $0.08 \mathrm{~g}$ indigestible dry material. The total dry percentage is $31.4 \%$.

The overall energy density of the food of Archegosaurus can be estimated as follows:

$$
\begin{aligned}
& (0)\left(15.9 \mathrm{~kJ} \mathrm{~g}^{-1} \text { carbohydrate }\right)+(0.686)\left(0 \mathrm{~kJ} \mathrm{~g}^{-1} \text { water }\right) \\
& +(0.189)\left(20 \mathrm{~kJ} \mathrm{~g}^{-1} \text { protein }\right)+(0.045)\left(39.2 \mathrm{kJg}^{-1} \text { fat }\right) \\
& +(0.08)\left(0 \mathrm{~kJ} \mathrm{~g}^{-1} \text { indigestible }\right)=5.5 \mathrm{kJg}^{-1} \text { food. }
\end{aligned}
$$

\section{A11 Estimation of food absorption}

Absorption in the Archegosaurus model can be estimated as follows. The average daily metabolic rate in Archegosaurus is $\mathrm{ADMR}=19 \mathrm{~kJ} \mathrm{~h}^{-1}=456 \mathrm{~kJ} \mathrm{day}^{-1}$. Therefore, the grams of food per day that have to be assimilated can be estimated as $\mathrm{g}$ food $/$ day $=\left(456 \mathrm{~kJ} \mathrm{day}^{-1}\right) /\left(5.5 \mathrm{~kJ} \mathrm{~g}^{-1}\right)=83 \mathrm{~g} \mathrm{day}^{-1}$ $=0.08 \mathrm{~kg} \mathrm{day}^{-1}$. From this, the amount of protein and fat that must be assimilated per day can be estimated: protein: $(18.9 \%)\left(83 \mathrm{~g} \mathrm{day}^{-1}\right)=16 \mathrm{~g} \mathrm{day}^{-1}$, conversion to moles: $\left(16 \mathrm{~g} \mathrm{day}^{-1}\right) /\left(2724 \mathrm{~g} \mathrm{~mol}^{-1}\right)=0.006 \mathrm{~mol} \mathrm{day}^{-1}$; fat: $(4.5 \%)\left(83 \mathrm{~g} \mathrm{day}^{-1}\right)=3.7 \mathrm{day}^{-1}$, conversion to moles: $\left(2.90 \mathrm{~g} \mathrm{day}^{-1}\right) /\left(180 \mathrm{~g} \mathrm{~mol}^{-1}\right)=0.02 \mathrm{~mol} \mathrm{day}^{-1}$. 


\section{A12 Estimation of assimilation}

The kilograms of food per day that Archegosaurus had to consume to assimilate $0.08 \mathrm{~kg}$ can be estimated as follows: in extant amphibians, assimilation energy ranges from 65 to $95 \%$ (Hillman et al., 2009); therefore, $80 \%$ assimilation energy is assumed here. To assimilate $0.08 \mathrm{~kg}$, Archegosaurus had to feed $0.08 / 0.80=0.1 \mathrm{~kg}$ of food per day. If we assume that an acanthodian of ca. $8 \mathrm{~cm}$ body length had a weight of around $15 \mathrm{~g}$ (compare living goldfish), then Archegosaurus had to eat about six fish of this size per day.

\section{A13 Estimation of osmotic water gain}

Water flux $F_{\text {water }}$ is described by the following equation: $F_{\text {water }}=\left(L_{\text {hyd }}\right)(\mathrm{SA})\left(\Pi_{\text {in }}-\Pi_{\text {out }}\right)\left(\right.$ in g water s $\left.{ }^{-1}\right)$, with

$L_{\text {hyd }}=$ hydraulic permeability $=P_{\mathrm{osm}}\left(\mathrm{cm} \mathrm{s}^{-1}\right) /$

$$
1.35 \times 10^{5} \mathrm{kPa}\left(\text { in } \mathrm{cm}\left(\mathrm{s}^{-1} \mathrm{kPa}^{-1}\right)\right)
$$

$P_{\text {osm }}=$ osmotic permeability $=0.79 \mu \mathrm{m} \mathrm{s}^{-1}$ for eel skin

(Withers, 1992, table 16-2) $=0.000079 \mathrm{~cm} \mathrm{~s}^{-1}$

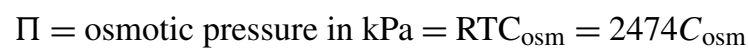

at $25^{\circ} \mathrm{C}$ ( $R$ is gas constant, $T$ is temperature,

and $C_{\text {osm }}$ is osmotic concentration in $\mathrm{molL}^{-1}$ )

$\mathrm{SA}_{\text {total }}=$ surface area of body

and gills $=4000 \mathrm{~cm}^{2}($ body surface $)+5280 \mathrm{~cm}^{2}$

$($ gill surface $)=9280 \mathrm{~cm}^{2}$.

In body fluids, the osmotic concentration $C_{\text {osm }}$ body is $205 \mathrm{mOsm}$ (see Sect. 7) $=0.21 \mathrm{~mol} \mathrm{~L}^{-1}$; in water, it is $C_{\text {osm }}$ water $=50 \mathrm{mOsm}=0.05 \mathrm{~mol} \mathrm{~L}^{-1}$.

$$
\begin{aligned}
& \begin{array}{l}
L_{\mathrm{hyd}}=\left(0.000079 \mathrm{~cm} \mathrm{~s}^{-1}\right) /(135000 \mathrm{kPa}) \\
\quad=5.85 \times 10^{-10} \mathrm{~cm}\left(\mathrm{~s}^{-1} \mathrm{kPa}^{-1}\right)
\end{array} \\
& \mathrm{SA}_{\text {total }}=9280 \mathrm{~cm}^{2} \\
& \Pi_{\text {in }}=(2479)\left(C_{\text {osm }} \text { body }\right)=(2479)(0.21)=521 \mathrm{kPa} \\
& \Pi_{\text {out }}=(2479)\left(C_{\text {osm }} \text { water }\right)=(2479)(0.05)=124 \mathrm{kPa} \\
& \Pi_{\text {in }}-\Pi_{\text {out }}=521-124 \mathrm{kPa}=397 \mathrm{kPa}
\end{aligned}
$$

Then the estimation of water flux is as follows:

$$
\begin{aligned}
& F_{\text {water }}=\left(L_{\text {hyd }}\right)(\mathrm{SA})\left(\Pi_{\text {in }}-\Pi_{\text {out }}\right) \\
& \left.=\left(5.85 \times 10^{-10} \mathrm{~cm}^{-1} \mathrm{kPa}^{-1}\right)\right)\left(9280 \mathrm{~cm}^{2}\right)(397 \mathrm{kPa}) \\
& =0.002 \mathrm{~g} \text { water s}^{-1}=\left(0.002 \mathrm{~g} \text { water s}^{-1}\right)\left(60 \mathrm{~s} \mathrm{~min}^{-1}\right) \\
& \left(60 \mathrm{minh}^{-1}\right)\left(24 \mathrm{~h} \mathrm{day}^{-1}\right)=172.8 \mathrm{~g} \text { water. }^{-1}
\end{aligned}
$$

This means that about $173 \mathrm{~g}$ water per day was gained through skin and gills in the Archegosaurus model.

\section{A14 Estimation of urea excretion}

According to Withers (1992), $100 \mathrm{~g}$ of protein yields 1.14 mol ammonia. As estimated in the digestion model (see
Appendix A11), Archegosaurus assimilated $16 \mathrm{~g}$ of protein per day. Therefore, it produced $0.18 \mathrm{~mol}$ ammonia per day. In the Archegosaurus model, $90 \%$ of it was excreted via the gills and the skin, and $10 \%$ was transformed into urea and released as dilute urine via the kidneys. From this, it follows that $(10)(0.18 \mathrm{~mol}) / 100=0.018 \mathrm{~mol}$ urea was excreted per day in the Archegosaurus model.

\section{A15 Estimation of gain and loss of $\mathrm{Na}^{+}$and $\mathrm{Cl}^{-}$}

Loss via the gills. The efflux of $\mathrm{Na}^{+}$via the gills in rainbow trout is $8.8 \mathrm{nmol} \mathrm{g}^{-1} \mathrm{~min}^{-1}$ under routine conditions (Gonzalez and McDonald, 1992, table 1). Taking this value for the Archegosaurus model, $0.0088 \mathrm{mmol} \mathrm{kg}^{-1} \mathrm{~min}^{-1} \times 60 \mathrm{~min} \times 24 \mathrm{~h} \times 7 \mathrm{~kg}=89 \mathrm{mmol}$ of $\mathrm{Na}^{+}$per day was lost by diffusion via the gills. This means for $\mathrm{NaCl}$ that $2 \times 89 \mathrm{mmol} \mathrm{day}^{-1}=178 \mathrm{mmol} \mathrm{day}^{-1}$ was passively lost through the gills.

Loss via the skin. Bentley (1962) cited the estimation of Wikgren (1953) that $\mathrm{Cl}^{-}$loss via the skin in the carp accounts for $0.05 \mathrm{nmol} \mathrm{cm}^{-2} \mathrm{~h}^{-1}$. If we assume the same value for the skin of Archegosaurus (which may have been more similar to a teleost than to an extant amphibian; see Sects. 4.2 and 5) and consider the body surface of $4000 \mathrm{~cm}^{2}$ estimated above, then the loss of $\mathrm{Cl}^{-}$per day can be estimated as follows: $0.00005 \mathrm{mmol} \mathrm{cm}^{-2} \mathrm{~h}^{-1} \times 4000 \mathrm{~cm}^{2} \times 24 \mathrm{~h} \mathrm{day}^{-1}$ $=4.8 \mathrm{mmol} \mathrm{day}^{-1}$ for $\mathrm{Cl}^{-}$, i.e., a value of $9.6 \mathrm{mmol} \mathrm{day}^{-1}$ for $\mathrm{NaCl}$ was lost through the skin.

Loss via urine. Freshwater fishes have a urine volume flow rate of $3 \mathrm{~mL} \mathrm{~kg}^{-1} \mathrm{~h}^{-1}$, with a urine concentration of $20 \mathrm{mOsm}$ (Hickman and Trump, 1969). Calculation of volume multiplied with concentration yields the loss of solutes in the Archegosaurus model: $\left(3 \mathrm{~mL} \mathrm{~kg}^{-1} \mathrm{~h}^{-1}\right)(7 \mathrm{~kg})\left(20 \mathrm{mmol} \mathrm{L}^{-1}\right)=0.42 \mathrm{mmol} \mathrm{h}^{-1}$. The loss of solutes (mainly $\mathrm{NaCl}$ ) per day accounts for $\left(0.42 \mathrm{mmol} \mathrm{h}^{-1}\right)\left(24 \mathrm{~h} \mathrm{day}^{-1}\right)=10 \mathrm{mmol}$ per day.

Uptake by chloride cells in the gills. The trout shows an active uptake of approximately $0.5 \mathrm{mmol} \mathrm{kg} \mathrm{g}^{-1} \mathrm{~h}^{-1}$ of both $\mathrm{Na}^{+}$and $\mathrm{Cl}^{-}$through the whole body (the bulk of which is taken up through chloride cells in the gills) (Perry et al., 1992, fig. 6), and a similar uptake has been reported for the zebra fish (Boisen et al., 2003). Extrapolated to the Archegosaurus model with a body mass of $7 \mathrm{~kg}$, this would mean that $\left(0.5 \mathrm{mmol} \mathrm{kg}^{-1} \mathrm{~h}^{-1}\right)(7 \mathrm{~kg})\left(24 \mathrm{~h} \mathrm{day}^{-1}\right)=$ $84 \mathrm{mmol} \mathrm{day}^{-1}$ of $\mathrm{Na}^{+}$or $\mathrm{Cl}^{-}$was actively taken up via the gills. Consequently, $2 \times 84=168 \mathrm{mmol}$ of $\mathrm{NaCl}$ was taken up per day.

Uptake by nutrition. As estimated above, the Archegosaurus model ingests $100 \mathrm{~g}(=0.1 \mathrm{~L})$ of acanthodian meat per day, for which we chose shark meat as the extant analog. Modern sharks have a concentration 
of $500 \mathrm{mmol}$ of $\mathrm{NaCl}$ in their plasma (Karnaky, 1998).

Consequently, the daily uptake of $\mathrm{NaCl}$ via the prey in the Archegosaurus model is $0.1 \mathrm{~L} \times 500 \mathrm{mmol}=50 \mathrm{mmol}$. 
Competing interests. The authors declare that they have no conflict of interest.

Acknowledgements. This work arose during the Comparative Physiology seminar that was held in spring 2015 at the Department of Ecology and Evolutionary Biology, Brown University, Providence, USA. We thank all the participating students for many fruitful discussions. Florian Witzmann thanks the Alexander von Humboldt Foundation (http://www.humboldt-foundation.de) for financial support. The comments of the two reviewers, Estevan Eltink and Marcello Ruta, greatly improved the paper.

Edited by: T. Scheyer

Reviewed by: M. Ruta and E. Eltink

\section{References}

Babiker, M. M.: Development of dependence on aerial respiration in Polypterus senegalus (Cuvier), Hydrobiologia, 110, 351-363, 1984.

Bartsch, P.: Cladistia (Polypteriformes, Brachiopterygii), Flösselhechte und Flösselaal, in: Spezielle Zoologie: Wirbel- oder Schädeltiere, edited by: Westheide, W. and Rieger, R., Volume 2, Spektrum Akademischer Verlag, Heidelberg and Berlin, 228232, 2004.

Bassi, M., Klein, W., Fernandes, M. N., Perry, S. F., and Glass, M. L.: Pulmonary oxygen diffusing capacity of the South American lungfish Lepidosiren paradoxa: physiological values by the Bohr method, Physiol. Biochem. Zool., 78, 560-569, 2005.

Baxter, R. M., Prosser, M. V., Talling, J. F., and Wood, R. B.: Stratification in tropical African lakes at moderate altitudes (1,500 to 2,000 m), Limnol. Oceanogr., 10, 510-520, 1965.

Becq-Giraudon, J.-F., Montenant, C., and Van den Driessche, J.: Hercynian high-altitude phenomenon the French Massif Centrale: tectonic implications, Paleogeogr. Paleoclimat. Paleoecol., 122, 227-241, 1996.

Benson, R. B., Butler, R. J., Carrano, M. T., and O'Connor, P. M.: Air-filled postcranial bones in theropod dinosaurs: physiological implications and the 'reptile'-bird transition, Biol. Rev., 87, 168193, 2012.

Bentley, P. J.: Permeability of the skin of the cyclostome Lampetra fluviatilis to water and electrolytes, Comp. Biochem. Physiol., 6, 95-97, 1962.

Berner, R. A.: GEOCARBSULF: a combined model for Phanerozoic atmospheric $\mathrm{O}_{2}$ and $\mathrm{CO}_{2}$, Geochim. Cosmochim. Acta, 70, 5653-5664, 2006.

Berner, R. A. and Kothavala, Z.: GEOCARB III: a revised model of atmospheric $\mathrm{CO}_{2}$ over Phanerozoic time, Am. J. Sci., 301, 182204, 2001.

Boisclair, D. and Sirois, P.: Testing assumptions of fish bioenergetics models by direct estimation of growth, consumption, and activity rates, Transactions of the American Fisheries Society, 122, 784-796, 1993.

Boisen, A. M. Z., Amstrup, J., Novak, I., and Grosell, M.: Sodium and chloride transport in soft water and hard water acclimated zebrafish (Danio rerio), Biochimica et Biophysica Acta (BBA)Biomembranes, 1618, 207-218, 2003.
Boy, J. A.: Die Larven der rhachitomen Amphibien (Amphibia: Temnospondyli; Karbon-Trias), Palaeont. Z., 48, 236-268, 1974.

Boy, J. A.: Synopsis of the tetrapods from the Rotliegend (Lower Permian) in the Saar-Nahe Basin (SW-Germany), Pollichia Buch, 29, 155-169, 1993.

Boy, J. A.: Seen der Rotliegend-Zeit: ein Lebensraum vor rund 300 Millionen Jahren in der Pfalz, in: Erdgeschichte im Rheinland, edited by: Koenigswald, W. and Meyer, W., Verlag Dr. Friedrich Pfeil, München, 107-116, 1994.

Boy, J. A. and Schindler, T.: Ökostratigraphie des Rotliegend, in: Deutsche Stratigraphische Kommission, edited by: Lützner, H. and Kowalczyk, G., Stratigraphie von Deutschland. X. Rotliegend. Teil I: Innervariscische Becken, Schriftenreihe der Deutschen Gesellschaft für Geowissenschaften, 61, 143-160, 2012.

Boy, J. A. and Sues, H.-D.: Branchiosaurs: Larvae, metamorphosis and heterochrony in temnospondyls and seymouriamorphs, in: Amphibian Biology, edited by: Heatwole, H. and Carroll, R. L., Volume 4, Surrey Beatty and Sons PTY limited, Chipping Norton, 1150-1197, 2000.

Brainerd, E. L.: Mechanical design of polypterid fish integument for energy storage during recoil aspiration, J. Zool. Lond., 232, 7-19, 1994.

Brainerd, E. L.: Mechanics of lung ventilation in a larval salamander, Ambystoma tigrinum, J. Exp. Biol., 201, 2891-2901, 1998.

Brainerd, E. L.: New perspectives on the evolution of lung ventilation mechanisms in vertebrates, Exp. Biol. Online, 4, 1-28, 1999.

Brainerd, E. L.: Major transformations in vertebrate breathing mechanisms, in: Great transformations in vertebrate evolution, edited by: Dial, K. P., Shubin, N., and Brainerd, E. L., University of Chicago Press, Chicago, 47-61, 2015.

Brainerd, E. L. and Ferry-Graham, L. A.: Mechanics of respiratory pumps, in: Fish Physiology, edited by: Shadwick, R. E. and Lauder, G. V., Volume 23: Fish Biomechanics, Academic Press, San Diego, 1-28, 2006.

Brainerd, E. L. and Monroy, J. A.: Mechanics of lung ventilation in a large aquatic salamander, Siren lacertina, J. Exp. Biol., 201, 673-682, 1998.

Brainerd, E. L. and Owerkowicz, T.: Functional morphology and evolution of aspiration breathing in tetrapods, Resp. Physiol. Neurobi., 154, 73-88, 2006.

Brainerd, E. L. and Simons, R. S.: Morphology and function of the lateral hypaxial musculature in salamanders, Amer. Zool., 40, 77-86, 2000.

Brainerd, E. L., Ditelberg, J., and Bramble, D. M.: Lung ventilation in salamanders and the evolution of vertebrate air-breathing mechanisms, Biol. J. Linn. Soc.-Lond., 49, 163-183, 1993.

Brainerd, E. L., Moritz, S., and Ritter, D. A.: XROMM analysis of rib kinematics during lung ventilation in the green iguana, Iguana iguana, J. Exp. Biol., 219, 404-411, 2016.

Brazeau, M. D. and Friedman, M.: The origin and early phylogenetic history of jawed vertebrates, Nature, 520, 490-497, 2015.

Britz, R. and Johnson, G. D.: On the homology of the posteriormost gill arch in polypterids (Cladistia, Actinopterygii), Zool. J. Linn. Soc.-Lond., 138, 495-503, 2003.

Bryant, H. N. and Russell, A. P.: The role of phylogenetic analysis in the inference of unpreserved attributes of extinct taxa, Phil. Trans. Roy. Soc. B., 337, 405-418, 1992. 
Burggren, W. W. and Johansen, K.: Circulation and respiration in lungfishes (Dipnoi), J. Morphol., 190, 217-236, 1986.

Carroll, R. L., Irwin, J., and Green, D. M.: Thermal physiology and the origin of terrestriality in vertebrates, Zool. J. Linn. Soc.Lond., 143, 345-358, 2005.

Cleuren, J. and de Vree, F.: Feeding in crocodylians, in: Feeding, edited by: Schwenk, K., New York, Boston, and London, Academic Press, 337-58, 2000.

Coates, M. I. and Clack, J. A.: Fish-like gills and breathing in the earliest known tetrapod, Nature, 352, 234-236, 1991.

Daeschler, E. B., Shubin, N. H., and Jenkins, F. A.: A Devonian tetrapod-like fish and the evolution of the tetrapod body plan, Nature, 440, 757-763, 2006.

Daxboeck, C., Barnard, D. K., and Randall, D. J.: Functional morphology of the gills of the bowfin, Amia calva L., with special reference to their significance during air exposure, Resp. Physiol., 43, 349-364, 1981.

Deban, S. M. and Wake, D. B.: Aquatic Feeding in Salamanders, in: Feeding, edited by: Schwenk, K., New York, Boston, and London, Academic Press, 65-94, 2000.

de Moraes, M. F., Höller, S., da Costa, O. T., Glass, M. L., Fernandes, M. N., and Perry, S. F.: Morphometric comparison of the respiratory organs in the South American lungfish Lepidosiren paradoxa (Dipnoi), Physiol. Biochem. Zool., 78, 546-559, 2005.

Diana, J. S.: Diel activity pattern and swimming speeds of northern pike (Esox lucius) in Lac Ste. Anne, Alberta, Can. J. Fish. Aquat. Sci., 37, 1454-1458, 1980.

Drane, C. R. and Webb, G. J. W.: Functional morphology of the dermal vascular system of the Australian lizard Tiliqua scincoides, Herpetologica, 36, 60-66, 1980.

Du, T. Y., Larsson, H. C. E., and Standen, E. M.: Observations of terrestrial locomotion in wild Polypterus senegalus from Lake Albert, Uganda, Afr. J. Aquat. Sci., 2016, 1-5, 2016.

Duellman, W. E. and Trueb, L.: Biology of amphibians, Johns Hopkins University Press, Baltimore, Maryland, 1994.

Eltink, E. and Langer, M. C.: A new specimen of the temnospondyl Australerpeton cosgriffi from the late Permian of Brazil (Rio do Rasto Formation, Paraná Basin): comparative anatomy and phylogenetic relationships, J. Vertebr. Paleontol., 34, 524-538, 2014.

Farina, S. C., Near, T. J., and Bemis, W. E.: Evolution of the branchiostegal membrane and restricted gill openings in actinopterygian fishes, J. Morphol., 276, 681-694, 2015.

Fischer, J., Schneider, J. W., Voigt, S., Joachimski, M. M., Tichomirowa, M., Tütken, T., Götze, J., and Berner, U.: Oxygen and strontium isotopes from fossil shark teeth: Environmental and ecological implications for Late Palaeozoic European basins, Chem. Geol., 342, 44-62, 2013.

Fortuny, J., Galobart, À., and De Santisteban, C.: A new capitosaur from the Middle Triassic of Spain and the relationships within the Capitosauria, Acta Palaeontol. Pol., 56, 553-566, 2011.

Fortuny, J., Marcé-Nogué, J., Steyer, J. S., de Esteban-Trivigno, S., Mujal, E., and Gil, L.: Comparative 3D analyses and palaeoecology of giant early amphibians (Temnospondyli: Stereospondyli), Sci. Rep., 6, 30387, doi:10.1038/srep30387, 2016.

Gardaire, E. and Isaia, J.: Potassium balance in freshwater-adapted trout Oncorhynchus mykiss, Comp. Biochem. Physiol. Part A, 103, 657-660, 1992.
Glasspool, I. J. and Scott, A. C.: Phanerozoic concentrations of atmospheric oxygen reconstructed from sedimentary charcoal, Nature Geosci., 3, 627-630, 2010.

Goldfuss, G. A.: Beiträge zur vorweltlichen Fauna des Steinkohlengebirges, Naturhistorischer Verein für die preussischen Rheinlande, Bonn, 1847.

Gonzalez, R. J. and McDonald, D. G.: The relationship between oxygen consumption and ion loss in a freshwater fish, J. Exp. Biol., 163, 317-332, 1992.

Graham, J. B.: Air-breathing fishes. Evolution, diversity and adaptation, Academic Press, San Diego, California, 1997.

Grigg, G. C. and Seebacher, F.: Crocodilian thermal relations, in: Crocodilian biology and evolution, edited by: Grigg, G. C., Seebacher, F., and Franklin, C. E., Surrey Beatty and Sons PTY limited, Chipping Norton, 297-309, 2001

Gubin, Y. M.: Skull morphology of Archegosaurus decheni Goldfuss (Amphibia, Temnospondyli) from the Early Permian of Germany, Alcheringa, 21, 103-121, 1997.

Hasumi, M. and Iwasawa, H.: Wandering behavior and cutaneous changes in winter-dormant male salamanders (Hynobius nigrescens), Herpetologica, 48, 279-287, 1992.

Heldmaier, G. and Neuweiler, G.: Vergleichende Tierphysiologie, Band 2: Vegetative Physiologie, Springer Verlag, Heidelberg, 2004.

Heusner, A. A.: Energy metabolism and body size I. Is the 0.75 mass exponent of Kleiber's equation a statistical artifact?, Resp. Physiol., 48, 1-12, 1982.

Hickman Jr., C. P. and Trump, B. F.: The kidney, in: Fish Physiology, edited by: Hoar, W. S. and Randall, D. J., Volume 1, Academic Press, New York and London, 91-239, 1969.

Hildebrand, M. and Goslow, G.: Analysis of Vertebrate Structure, fifth edition, Wiley and Sons, New York, 1998.

Hillman, S. S., Withers, P. C., Drewes, R. C., and Hillyard, S. D.: Ecological and environmental physiology of amphibians, Oxford University Press, Oxford, 2009.

Hofker, J.: Archegosaurus Decheni Goldfuss. Untersuchung des Schädelbaues, Palaeont. Hungarica, 2, 109-130, 1926.

Hughes, G. M.: A comparative study of gill ventilation in marine teleosts, J. Exp. Biol., 37, 28-45, 1960.

Hurlburt, G. R.: Comparison of body mass estimation techniques, using Recent reptiles and the pelycosaur Edaphosaurus boanerges, J. Vertebr. Paleontol., 19, 338-350, 1999.

Janis, C. M. and Farmer, C.: Proposed habitats of early tetrapods: gills, kidneys, and the water-land transition, Zool. J. Linn. Soc.Lond., 126, 117-126, 1999.

Janis, C. M. and Keller, J. C.: Modes of ventilation in early tetrapods: Costal aspiration as a key feature of amniotes, Acta Pal. Pol., 46, 137-170, 2001.

Jerison, H. J.: Evolution of the brain and intelligence, Academic Press, New York, 1973.

Karnaky Jr., K. J.: Osmotic and ionic regulation, in: The Physiology of Fishes, edited by: Evans, D. H., second edition, CRC Press, Boca Raton and New York, 157-176, 1998.

Killen, S. S., Atkinson, D., and Glazier, D. S.: The intraspecific scaling of metabolic rate with body mass in fishes depends on lifestyle and temperature, Ecol. Lett., 13, 184-193, 2010.

Kriwet, J., Witzmann, F., Klug, S., and Heidtke, U. H.: First direct evidence of a vertebrate three-level trophic chain in the fossil record, Proc. Roy. Soc.-Lond. B, 275, 181-186, 2008. 
Landolt, J. C. and Hill, L. G.: Observations of the gross structure and dimensions of the gills of three species of gars (Lepisosteidae), Copeia, 1975, 470-475, 1975.

Lauder, G. V. and Norton, S. F.: Asymmetric muscle activity during feeding in the gar, Lepisosteus oculatus, J. Exp. Biol., 84, 17-32, 1980.

Lauder, G. V. and Reilly, M. S.: Amphibian feeding behaviour: comparative biomechanics and evolution, in: Advances in comparative and environmental physiology 18: Biomechanics of feeding in vertebrates, edited by: Bels, V. L., Chardon, M., and Vandewalle, P., Springer Verlag, Berlin, 163-195, 1994.

Lechleuthner, A., Schumacher, U., Negele, R. D., and Welsch, U.: Lungs of Polypterus and Erpetoichthys, J. Morphol., 201, 161178, 1989.

Levine, R. P., Monroy, J. A., and Brainerd, E. L.: Contribution of eye retraction to swallowing performance in the northern leopard frog, Rana pipiens, J. Exp. Biol., 207, 1361-1368, 2004.

Licht, L. E. and Lowcock, L. A.: Genome size and metabolic rate in salamanders, Comp. Biochem. Physiol. B, 100, 83-92, 1991.

Lutz, P. L.: Osmotic and ionic composition of the polypteroid Erpetoichthys calabaris, Copeia, 1975, 119-123, 1975.

Maddin, H. C., Musat-Marcu, S., and Reisz, R. R.: Histological microstructure of the claws of the African clawed frog, Xenopus laevis (Anura: Pipidae): implications for the evolution of claws in tetrapods, J. Exp. Zool. B, 308, 259-268, 2007.

Magid, A. M. A., Vokac, Z., and Ahmed, N. E. D.: Respiratory function of the swim-bladders of the primitive fish Polypterus senegalus, J. Exp. Biol., 52, 27-37, 1970.

Marjanović, D. and Laurin, M.: The origin (s) of extant amphibians: a review with emphasis on the "lepospondyl hypothesis", Geodiversitas, 35, 207-272, 2013.

Martínez-Palacios, C. A., Salgado-García, R. L., Racotta, I. S., Campos-Mendoza, A., and Ross, L. G.: Effects of salinity on eggs, larvae, and juveniles of Blacknose Silversides from Lake Chapala, Mexico, N. Am. J. Aquacult, 70, 12-19, 2008.

Mayer, N.: Adaptation de Rana esculenta a des milieux varies. Etude speciale de l'excretion renale de l'eau et des electrolytes au cours des changements de milieu, Comp. Biochem. Physiol., 29, 27-50, 1969.

Nifong, J. C., Nifong, R. L., Silliman, B. R., Lowers, R. H., Guillette Jr., L. J., Ferguson, J. M., Welsh, M., Abernathy, K., and Marshall, G.: Animal-borne imaging reveals novel insights into the foraging behaviors and diel activity of a large-bodied apex predator, the American alligator (Alligator mississippiensis), PloS one, 9, e83953, doi:10.1371/journal.pone.0083953, 2014.

Owen, R.: Palaeontology, or a systematic summary of extinct animals and their geological relatives, A. and C. Black, Edinburgh, 1861.

Pace, C. M. and Gibb, A. C.: Locomotor behavior across an environmental transition in the ropefish, Erpetoichthys calabaricus, J. Exp. Biol., 214, 530-537, 2011.

Patzowsky, M. E., Smith, L. H., Markwick, P. J., Engberts, C. J., and Gyllenhaal, E. D.: Application of the Fujita-Ziegler paleoclimate model: Early Permian and Late Cretaceous examples, Paleogeogr. Paleoclimat. Paleoecol., 86, 67-85, 1991.

Perry, S. F., Goss, G. G., and Laurent, P.: The interrelationships between gill chloride cell morphology and ionic uptake in four freshwater teleosts, Can. J. Zool., 70, 1775-1786, 1992.
Pettit, M. J. and Beitinger, T. L.: Oxygen acquisition of the reedfish, Erpetoichthys calabaricus, J. Exp. Biol., 114, 289-306, 1985.

Pusey, B., Kennard, M., and Arthington, A.: Freshwater Fishes of North-Eastern Australia, CSIRO Publishing, 2004.

Rahn, H., Rahn, K. B., Howell, B. J., Gans, C., and Tenney, S. M.: Air breathing of the garfish (Lepisosteus osseus), Resp. Physiol., 11, 285-307, 1971.

Ruta, M. and Coates, M. I.: Dates, nodes and character conflict: addressing the lissamphibian origin problem, J. Syst. Palaeontol., 5, 69-122, 2007.

Sacca, R. and Burggren, W.: Oxygen uptake in air and water in the air-breathing reedfish Calamoichthys calabaricus: role of skin, gills and lungs, J. Exp. Biol., 97, 179-186, 1982.

Schindler, T.: Geologie, Stratigraphie und Genese des permokarbonischen Saar-Nahe Beckens, in: Kohlesümpfe, Seen und Halbwüsten, edited by: Schindler, T. and Heidtke, U. H. J., Pollichia, Bad Dürkheim, 4-37, 2007.

Schoch, R. R.: The evolution of major temnospondyl clades: an inclusive phylogenetic analysis, J. Syst. Palaeontol., 11, 673-705, 2013.

Schoch, R. R.: Amphibian evolution: the life of early land vertebrates, Wiley Blackwell, Chichester, 2014.

Schoch, R. R. and Milner, A.: Encyclopedia of Paleoherpetology 3B, Stereospondyli, Verlag Dr. Friedrich Pfeil, München, 2000.

Schoch, R. R. and Milner, A.: Encyclopedia of Paleoherpetology 3A2, Temnospondyli I, Verlag Dr. Friedrich Pfeil, München, 2014.

Schoch, R. R. and Witzmann, F.: The temnospondyl Glanochthon from the Lower Permian Meisenheim Formation of Germany, Special Papers in Palaeontology, 81, 121-136, 2009.

Schoch, R. R. and Witzmann, F.: Bystrow's Paradox-gills, fossils, and the fish-to-tetrapod transition, Acta Zoologica, 92, 251-265, 2011.

Schultze, H.-P.: Die Lungenfisch-Gattung Conchopoma (Pisces, Dipnoi), Senckenbergiana lethaea, 56, 191-231, 1975.

Schultze, H. P. and Soler-Gijón, R.: A xenacanth clasper from the uppermost Carboniferous Lower Permian of Buxières-les-Mines (Massif Central, France) and the palaeoecology of the European Permo-Carboniferous basins, Neues Jahrbuch fur Geologie und Paläontologie-Abhandlungen, 232, 325-363, 2004.

Sigurdsen, T. and Green, D. M.: The origin of modern amphibians: a re-evaluation, Zool. J. Linn. Soc.-Lond., 162, 457-469, 2011.

Simons, R. S., Bennett, W. O., and Brainerd, E. L.: Mechanics of lung ventilation in a post-metamorphic salamander, Ambystoma tigrinum, J. Exp. Biol., 203, 1081-1092, 2000.

Standen, E. M., Du, T. Y., and Larsson, H. C.: Developmental plasticity and the origin of tetrapods, Nature, 513, 54-58, 2014.

Ultsch, G. R.: Metabolism, gas exchange, and acid-base balance of giant salamanders, Biol. Rev., 87, 583-601, 2012.

Vogt, C.: Mittheilungen an Professor Bronn gerichtet, Neues Jahrbuch für Mineralogie, Geognosie, Geologie und PetrefaktenKunde, 1854, 676-677, 1854.

von Meyer, H.: Mittheilungen an Professor Bronn gerichtet, Neues Jahrbuch für Mineralogie, Geognosie, Geologieund PetrefaktenKunde, 1854, 422, 1854.

von Meyer, H.: Reptilien aus der Steinkohlenformation in Deutschland, Palaeontographica, 6, 59-219, 1858.

Wedel, M. J.: Vertebral pneumaticity, air sacs, and the physiology of sauropod dinosaurs, Paleobiology, 29, 243-255, 2003. 
Wikgren, B. J.: Osmotic regulation in some aquatic animals with special reference to the influence of temperature, Acta Zool. Fenn., 71, 1-102, 1953.

William, S. R.: The specific gravity of some fresh-water animals in relation to their habits, development, and composition, American Naturalist, 95-108, 1900.

Withers, P. C.: Comparative Animal Physiology, Saunders College Publishing, Orlando, Florida, 1992.

Witmer, L. M.: The extant phylogenetic bracket and the importance of reconstructing soft tissues in fossils, Functional Morphology in Vertebrate Paleontology, 1, 19-33, 1995.

Witmer, L. M.: Application of the extant phylogenetic bracket (EPB) approach to the problem of anatomical novelty in the fossil record, J. Vert. Palaeontol., 18 (3 Supplement), 87A, 1998.

Witzmann, F.: Morphology and paleobiology of the PermoCarboniferous temnospondyl amphibian Archegosaurus decheni Goldfuss, 1847 from the Saar-Nahe Basin, Germany, PhD thesis, Humboldt University, Berlin, 2004a.

Witzmann, F.: The external gills of Palaeozoic amphibians, Neues Jahrbuch für Geologie und Paläontologie, Abhandlungen, 232, 375-401, 2004b.

Witzmann, F.: Cranial morphology and ontogeny of the PermoCarboniferous temnospondyl Archegosaurus decheni Goldfuss, 1847 from the Saar-Nahe Basin, Germany, Trans. Roy. Soc. Edinb.: Earth Sciences, 96, 131-162, 2006a.

Witzmann, F.: Developmental patterns and ossification sequence in the Permo-Carboniferous temnospondyl Archegosaurus decheni (Saar-Nahe Basin, Germany), J. Vertebr. Paleontol., 26, 7-17, 2006b.
Witzmann, F.: The evolution of the scalation pattern in temnospondyl amphibians, Zool. J. Linn. Soc.-Lond., 150, 815-834, 2007.

Witzmann, F.: Morphological and histological changes of dermal scales during the fish-to-tetrapod transition, Acta Zool., 92, 281302, 2011.

Witzmann, F.: Phylogenetic patterns of character evolution in the hyobranchial apparatus of early tetrapods, Earth and Environmental Science Transactions of the Royal Society of Edinburgh, 104, 145-167, 2013.

Witzmann, F.: $\mathrm{CO}_{2}$-metabolism in early tetrapods revisited - inferences from osteological correlates of gills, skin and lung ventilaton in the fossil record, Lethaia, 49, 492-506, 2016.

Witzmann, F. and Schoch, R. R.: The postcranium of Archegosaurus decheni, and a phylogenetic analysis of temnospondyl postcrania, Palaeontology, 49, 1211-1235, 2006.

Witzmann, F., Scholz, H., Müller, J., and Kardjilov, N.: Sculpture and vascularization of dermal bones, and the implications for the physiology of basal tetrapods, Zool. J. Linn. Soc.-Lond., 160, 302-340, 2010.

Wright, P. A.: Ionic, osmotic, and nitrogenous waste regulation, in: Fish physiology: primitive fishes, volume 26, edited by: McKenzie, D. J., Farrell, A. P., and Brauner, C. J., Volume 26, Academic Press, San Diego, 283-318, 2007.

Zhu, M., Yu, X., Ahlberg, P. E., Choo, B., Lu, J., Qiao, T., Qu, Q, Zhao, W., Jia, L., Blom, H., and Zhu, Y. A.: A Silurian placoderm with osteichthyan-like marginal jaw bones, Nature, 502, 188-193, 2013. 